Schulich School of Law, Dalhousie University

Schulich Law Scholars

Preventing Salmon Escapes from Aquaculture in Canada and the USA: Limited International Coordinates, Divergent Regulatory Currents and Possible Future Courses

David VanderZwaag

Tricia Barry

Follow this and additional works at: https://digitalcommons.schulichlaw.dal.ca/scholarly_works

Part of the Environmental Law Commons 


\section{Preventing Salmon Escapes from Aquaculture in Canada and the USA: Limited International Coordinates, Divergent Regulatory Currents and Possible Future Courses}

\section{Tricia K. Barry and David L. VanderZwaag}

Following an introductory review of the continuing problem of salmon escaping from aquaculture operations along the Atlantic and Pacific coasts of North America, and the considerable uncertainties over ecological impacts, this article examines the law and policy context for preventing escapes from three perspectives. First, the limited guidance for addressing aquaculture escapes under existing global and regional agreements/arrangements is highlighted. Second, how Canada and the USA have sought to control escape events at national and provincial/State levels is summarized. Third, possible future courses are identified, which improve the way salmon escapes are addressed, with stronger regional responses suggested as most promising. Enhancing the North Atlantic Salmon Conservation Organization's role in preventing escapes and placing transboundary aquaculture issues on the agendas of North Pacific regional cooperative arrangements are the potential courses emphasized.

\section{INTRODUCTION}

Escape of farmed salmon into the marine environment, while difficult to estimate accurately due to limited reporting, ${ }^{1}$ is worrying because of the large numbers of escapes known to have occurred. For example, in British Columbia (BC), between 1987 and 2000, 87 escape incidents were reported with a loss of 1,313,237 fish. ${ }^{2}$ In Washington State, from 1996 to 1998, three large-scale events allowed 595,000 fish to escape. ${ }^{3}$ In

\footnotetext{
${ }^{1} \mathrm{~J}$. Volpe, Super Un-Natural - Atlantic Salmon in BC Waters (David Suzuki Foundation, 2001), at 15, available at <http://www.davidsuzuki. org/files/Super_Un_Natural.pdf>

${ }^{2}$ See British Columbia Ministry of Agriculture and Lands, Aquaculture Development Branch, Escape Statistics (British Columbia Ministry of Agriculture and Lands, 2005), available at <http://www.agf.gov.bc.ca/ fisheries/escape/escape_reports.htm>.

${ }^{3}$ See Alaska Department of Fish and Game - Southeast Region, Atlantic Salmon: A White Paper (Alaska Department of Fish and Game, 2002), at 1, available at <http://www.state.ak.us/adfg/geninfo/special/As/ docs/As_white2002.pdf> ('White Paper').
}

November 2005, tens of thousands of mature salmon escaped in New Brunswick. ${ }^{4}$

Preventing escapes has been a challenge because of the multiple ways that releases can occur. Among the causes of escapes are poor net maintenance, storm damage, accidental losses during transfers, tearing of nets by boat collisions or predators, and vandalism. ${ }^{5}$

While considerable uncertainties continue to exist over the impacts of escaped salmon, the capacity for escapees to affect wild salmon stocks adversely is becoming increasingly documented. ${ }^{6}$ Impacts of concern include hybridization; colonization by establishing significant, self-sustaining runs; ${ }^{7}$ interbreeding causing reduced

\footnotetext{
${ }^{4}$ See Atlantic Salmon Federation (ASF) - Communications, Conservationists Fed Up with Government's Inaction on Farmed Salmon Escapes (ASF, 16 November 2005), available at <http:// www.asf.ca/Communications/2005/11/farmedescapes2.html>.

${ }^{5}$ See M.L. Brenninkmeyer, 'The Ones That Got Away: Regulating Escaped Fish and Other Pollutants from Salmon Fish Farms', 27:1 B.C. Envtl. Aff. L. Rev. (1999), 75, at 83. Four confirmed acts of vandalism in Canada in 2005 resulted in approximately 150,000 farmed fish being released to the wild. See NASCO, Report of the Twenty-Third Annual Meeting of the Council, Saariselkä Finland (CNL(06)46, 9 June 2006), at 210 ('Report of the Twenty-Third Meeting').

${ }^{6}$ C. Clover, 'Wild Salmon Put at Risk as a Million Farmed Fish Escape', The Daily Telegraph (29 August 2006), available at <http://www.telegraph. co.uk/news/main.jhtml?xml=/news/2006/08/29/nfish29.xml>.

${ }^{7}$ Two recent studies have demonstrated the effect of escapes on wild species. A study that simulated escapes over 10 years in the Atlantic Ocean near Scotland found that farmed Atlantic salmon have both a genetic and competitive impact on wild populations because over time the two species will interbreed and the next generation of hybrids has shown reduced survival and adult return. See P. McGinnity et al., 'Fitness Reduction and Potential Extinction of Wild Populations of Atlantic Salmon Salmo salar as a Result of Interactions with Escaped Farm Salmon', 270:1532 Proceedings Royal Society London B (7 December 2003), 2443, available at: <http://www.journals.royalsoc. ac.uk/(2miepx45ddk1usrvl0pu3myv)/app/home/journal.asp?referrer =parent\&backto=linkingpublicationresults, 1:102024,1\&linkin=>. In another article, the biological and socioeconomic risks of escapes were found to be large 'when salmon are farmed in their native range, when large numbers of salmon are farmed relative to the size of the
} 
genetic diversity and fitness; predation of native species; competition for space or resources potentially disrupting wild salmon production; disease transmission; and modification or destruction of the habitat of native species. ${ }^{8}$

The ability of escaped salmon to move across national boundaries raises transboundary management issues and challenges. Most sonically tagged farmed Atlantic salmon released in Maine followed the dominant tidal currents into Canadian waters. ${ }^{9}$ Quite a few salmon occurring in rivers in Maine are suspected to have originated from releases in Canada. ${ }^{10}$ On the west coast, Atlantic salmon, not allowed to be reared in aquaculture off the coast of Alaska, have been found in Alaskan waters with estimates that about 3000 escaped salmon may be present annually. ${ }^{11}$

This article examines prevention of escape challenges and approaches through a three-part discussion. A review of the limited global and regional coordinates in law and policy is followed by an overview of how Canada (including British Columbia and the Atlantic provinces) and the USA (including Washington State and Alaska) have sought to control escape events. The article then suggests possible future courses to improve the way salmon escapes are addressed, including possible amendments to existing conventions in place to conserve wild salmon stocks.

\section{LIMITED GLOBAL AND REGIONAL COORDINATES}

In the absence of a global treaty specific to aquaculture, and with no formal US-Canada agreements specifically targeting aquaculture developments carrying transboundary threats, international law and policy coordinates relevant to salmon escapes are limited and must be gleaned from existing global and regional agreements and arrangements. At the global level, the 1982 United Nations Convention on the Law of the Sea (UNCLOS), ${ }^{12}$ the 1992 Convention on Biological

wild population, and when exotic pathogens are introduced'. See R. Naylor et al., 'Fugitive Salmon: Assessing the Risks of Escaped Fish from Net-Pen Aquaculture', 55:5 BioScience (May 2005), 427. ${ }^{8} \mathrm{~J}$. Gardner and D. Peteson, Making Sense of the Aquaculture Debate (Pacific Fisheries Resource Conservation Council, 2003), at 90 and 94, available at <http://www.watershed-watch.org/PDFs/ PFRCC_FullReport.pdf>.

${ }^{9}$ F.G. Whoriskey et al., 'Movements and Survival of Sonically Tagged Farmed Atlantic Salmon Released in Cobstock Bay, Maine, USA', 63:7 ICES Journal of Marine Science (2006), 1218.

${ }^{10}$ See Report of the Twenty-third Meeting, n. 5 above, at 216.

${ }^{11}$ See White Paper, n. 3 above, at 5.

12 United Nations Convention on the Law of the Sea (Montego Bay, 10 December 1982). While the USA is not a party to the convention, many, if not most, of the convention's provisions are codifications of customary international law. See J.A. Duff, 'United States and the Law of the Sea Convention: Sliding Back from Accession and Ratification', 11:1\&2 Ocean and Coastal L.J. (2005-2006), 1, at 10.
Diversity (CBD), ${ }^{13}$ and the United Nations Food and Agriculture Organization Code of Conduct for Responsible Fisheries ('FAO Code') (also meant to apply to aquaculture operations) ${ }^{14}$ include provisions relevant to the issue of salmon escapes. For the North Atlantic region, the North Atlantic Salmon Conservation Organization (NASCO) has addressed issues of escape in various ways, including adoption of Guidelines on Containment of Farm Salmon (NASCO Guidelines), ${ }^{15}$ while the Gulf of Maine Council on the Marine Environment has largely ignored transboundary escape concerns. For the North Pacific region, the two legal agreements aimed at conserving wild salmon, the Pacific Salmon Treaty (PST) ${ }^{16}$ and Convention for the Conservation of Anadromous Stocks in the North Pacific Ocean, ${ }^{17}$ have not spawned efforts to address escaped salmon, while the British Columbia/Washington State Environmental Cooperation Agreement has not been extended to cover escaped salmon. ${ }^{18}$

\section{GLOBAL COORDINATES}

Law of the Sea Convention Besides setting out general obligations on States to protect and preserve the marine environment, ${ }^{19}$ to undertake environmental impact assessment of proposed activities that may cause significant and harmful changes to the marine environment ${ }^{20}$ and to protect/preserve the habitat of threatened or endangered species, ${ }^{21}$ the UNCLOS has only one article especially relevant to escaped salmon. Article 196 requires States to 'take all measures necessary to prevent, reduce and control ... the intentional or accidental introduction of species, alien or new, to a particular part of the marine environment, which may cause significant and harmful changes thereto'. While this provision is potentially applicable to the introduction of non-native salmon in marine waters, it leaves considerable room for interpretation as to what are 'all necessary measures'.

\footnotetext{
${ }^{13}$ Convention on Biological Diversity (Rio de Janeiro, 5 June 1992).

${ }^{14}$ Food and Agriculture Organization Code of Conduct for Responsible Fisheries (FAO, 1995) ('FAO Code').

${ }^{15}$ NASCO Guidelines on Containment of Farm Salmon (CNL(01)53, June 2003). The guidelines are attached as Annex 3 to the Williamsburg Resolution, adopted at the Twentieth Annual Meeting of NASCO in June 2003. See Resolution by the Parties to the Convention for the Conservation of Salmon in the North Atlantic Ocean to Minimize Impacts from Aquaculture, Introductions and Transfers, and Trangenics on the Wild Salmon Stocks (CNL(03)57, 2003) ('Williamsburg Resolution').

${ }^{16}$ Exchange of Notes Constituting an Agreement relating to the Treaty Concerning Pacific Salmon of 28 January 1985 (Washington DC, 30 June 1999).

${ }^{17}$ Convention for the Conservation of Anadromous Stocks in the North Pacific Ocean (Moscow, 11 February 1992) ('NPAFC Convention').

${ }^{18}$ Environmental Cooperation Agreement, Between the Province of $\mathrm{BC}$ and the State of Washington (Olympia, Washington, 7 May 1992) (ECA), available at <http://www.env.gov.bc.ca/spd/ecc/index.html>.

${ }^{19}$ See UNCLOS, n. 12 above, Article 192.

${ }^{20}$ Ibid., Article 206.

${ }^{21}$ Ibid., Article 194(5).
} 
Article 66 of the UNCLOS specifically addresses conservation of anadromous stocks ${ }^{22}$ but is largely focused on the control of fishing activities and not aquaculture. For example, Article 66 requires that fisheries for anadromous stocks must be conducted only in waters that are landward of the outer limits of exclusive economic zones (EEZs), except where this would cause economic dislocation for a State other than the country of origin. ${ }^{23}$ Only a general duty of cooperation in conservation and management is set out where anadromous stocks migrate beyond the State of origin to waters within EEZs of other States. ${ }^{24}$

If escaped salmon were considered a pollutant under the UNCLOS, which is highly questionable in light of the convention's definition of marine pollution, ${ }^{25}$ various other articles might also apply. For example, Article 294(2) requires States to take all measures necessary so that pollution arising from incidents/activities under their jurisdiction or control does not spread beyond the areas where they exercise sovereign rights.

\section{Convention on Biological Diversity Although} the USA is not yet a party to the $\mathrm{CBD},{ }^{26}$ the convention contains various provisions that might be applied to the problem of escaped salmon, at least aspirationally. ${ }^{27}$ Article 3 reiterates the State responsibility principle for transboundary harm, ${ }^{28}$ which stipulates that 'States

\footnotetext{
${ }^{22}$ Anadromous fish are those which go from fresh water to salt water and return to spawn, and include salmon species.

${ }^{23}$ See UNCLOS, n. 12 above, Article 66(3)(a).

${ }^{24}$ Ibid., Article 66(4). It states: 'In cases where anadromous stocks migrate into and through the waters landward of the outer limits of the exclusive economic zone of a State other than the State of origin, such State shall cooperate with the State of origin with regard to the conservation and management of such stocks'.

${ }^{25}$ Ibid., Article 1(4). This article defines pollution of the marine environment in terms of substances and energy: ' $[$ t] he introduction by man, directly or indirectly, of substances or energy into the marine environment, including estuaries, which results or is likely to result in such deleterious effects as harm to living resources and marine life, hazards to human health, hindrance to marine activities, including fishing and other legitimate uses of the sea, impairment of the quality for use of sea water and reduction of amenities . . . For a discussion of fish being treated as pollutants under national laws, see J. Firestone and R. Barber, 'Fish as Pollutants: Limitations of and Crosscurrents in Law, Science, Management, and Policy', 78:3 Washington L. Rev. (2003), 693. ${ }^{26}$ Although the USA signed the convention on 4 June 1993, it is not a party. See the website available at <http://www.biodiv.org/world/map.aspx>. ${ }^{27}$ Some of the provisions, especially the principle of State responsibility for transboundary damage set out in Article 3, have arguably attained the status of customary international law in light of wide acceptance in State practice combined with opinio juris that States feel they are legally bound. For a review of customary law formation, see P.W. Birnie and A.E. Boyle, International Law and the Environment, 2nd edn (Oxford University Press, 2002), at 16-18.

${ }^{28}$ It should be noted that the International Court of Justice in the Legality of the Threat or Use of Nuclear Weapons Case stated: 'The existence of the general obligation of States to ensure that activities within their jurisdiction and control respect the environment of other States or of areas beyond national control is now part of the corpus of international law relating to the environment. See ICJ 8 July 1996, Legality of the Threat or Use of Nuclear Weapons [1996] 1 ICJ Rep. 226, at 241-242.
}

have ... the responsibility to ensure that activities within their jurisdiction or control do not cause damage to the environment of other States or of areas beyond the limits of national jurisdiction'. ${ }^{29}$ Whether escaped salmon that cross national boundaries are causing 'damage' is, of course, a threshold issue.

The CBD also includes transboundary procedural guidelines potentially applicable to salmon farms and their escapes..$^{30}$ Article 14(1)(c) encourages parties to notify, exchange information and consult over activities under their jurisdiction or control which are likely to have a significant adverse effect on the biological diversity of other States. Parties are urged to conclude bilateral, regional and multilateral arrangements to flesh out their procedural responsibilities. Article 14(1)(d) calls on parties to notify potentially affected States of imminent or grave danger or damage to biological diversity, and to initiate action to prevent or minimize such danger or damage.

Article 8(h) bestows a general obligation to address the introduction of alien species. Each Contracting Party is required, as far as possible and as appropriate, to '[p]revent the introduction of, control or eradicate those alien species which threaten ecosystems, habitats or species .... Through Decision VIII/27, ${ }^{31}$ the Eighth Conference of the Parties (COP-8) to the CBD set out additional guidelines in relation to alien species and aquaculture. Parties and other governments are invited 'to promote aquaculture of native species with the aim to avoid accidental introduction of alien species and their parasites' ${ }^{32}$ At COP-8, regional bodies and convention regimes were encouraged to develop further cooperative arrangements for addressing risks of invasive alien species. ${ }^{33}$

Article 14(2) of the CBD calls upon the COP to examine the issue of liability and redress for damage to biological diversity, and the process has yet to be concluded. Following a report from the convention's Group of Legal and Technical Experts on Liability and Redress, ${ }^{34}$ the COP has requested the Executive Secretary of the $\mathrm{CBD}$ to prepare a synthesis report on approaches to

\footnotetext{
${ }^{29}$ An analysis of possible State liability for transboundary environmental damage is beyond the scope of this article. For a good discussion of the legal issues, see A.W. Boyle, 'Globalizing Environmental Liability: The Interplay of National and International Law', 17:1 Journal of Environmental Law (2005), 3.

${ }^{30}$ See CBD, n. 13 above, Article 14.

${ }^{31}$ Report of the Eighth Meeting of the Parties to the Convention on Biological Diversity (UNEP/CBD/COP/8/31, 15 June 2006), at 316 ('Report of the Eighth CBD Meeting').

${ }^{32} \mathrm{lbid}$., at 318, para. 24.

${ }^{33}$ Ibid., at para. 20.

${ }^{34}$ Conference of the Parties to the Convention on Biological Diversity, Eighth Meeting, Curitiba, Brazil, 20-31 March, 2006, Report of the Group of Legal and Technical Experts on Liability and Redress in the Context of Paragraph 2 of Article 14 of the Convention on Biological Diversity (UNEP/CBD/COP/8/27/Add.3, 18 October 2005).
} 
valuation and restoration relating to biological diversity damage by COP-9, scheduled to be held in $2008 .^{35}$

The CBD, through a preambular provision, also calls for the application of the precautionary approach. ${ }^{36}$ While the precautionary approach has been the subject of considerable controversy over what risks trigger application and how strong precautionary measures should be ${ }^{37}$ the approach could, at a minimum, be used to evaluate existing escape-prevention measures and to serve as an impetus to regulate in the face of uncertainty. ${ }^{38}$

A guidance document in sustainable mariculture, published by the Secretariat of the CBD, ${ }^{39}$ suggests a number of ways to prevent escapes. Application of environmental risk assessment before any introductions and use of sterile fish are recommended, along with making contingency measures mandatory in case of accidental escapes. ${ }^{40}$ The document encourages future finfish aquaculture to move towards closed systems to prevent farmed species from mixing with wild populations. ${ }^{41}$

FAO Code of Conduct While not a legally binding document, the FAO Code of Conduct for Responsible Fisheries specifically addresses aquaculture development in Article 9 with considerable attention given to the importance of protecting transboundary aquaculture ecosystems. States are urged to 'ensure responsible choice of species, siting and management of aquaculture activities which could affect transboundary ecosystems'; ${ }^{42}$ consult with their neighbouring States before introducing non-indigenous species into transboundary aquatic

\footnotetext{
${ }^{35}$ See Decision VIII/29, Liability and Redress, Report of the Eighth CBD Meeting, n. 31 above, at 345.

${ }^{36}$ The Preamble of the CBD states: 'Noting also that where there is a threat of significant reduction or loss of biological diversity, lack of full scientific certainty should not be used as a reason for postponing measures to avoid or minimize such a threat'. See CBD, n. 13 above, Preamble.

${ }^{37}$ For reviews, see S. Marr, The Precautionary Principle in the Law of the Sea: Modern Decision Making in International Law (Martinus Nijhoff, 2003); D.L. VanderZwaag, 'The Precautionary Principle and Marine Environmental Protection: Slippery Shores, Rough Seas and Rising Normative Tides', 33:2 Ocean Development \& International Law (2002), 165, at 166-168; and D. Freestone and E. Hey, 'Origins and Development of the Precautionary Principle', in D. Freestone and E. Hey (eds), The Precautionary Principle and International Law: The Challenge of Implementation (Kluwer Law International, 1996), at 3-15. ${ }^{38}$ For arguments in favour of a strong version whereby the proponents of development would bear the burden of showing no significant threats to the marine environment before being allowed to proceed, see R.G. Hildreth et al., 'Roles for a Precautionary Approach in Marine Resources Management', 19 Ocean Yearbook (2005), at 36. ${ }^{39}$ Report of the Ad Hoc Technical Expert Group on Mariculture, Solutions for Sustainable Mariculture - Avoiding the Adverse Effects of Mariculture on Biological Diversity (CBD Technical Series No 12, 2004) ('Solutions for Sustainable Mariculture'), available at <http:// www.biodiv.org/doc/publications/cbd-ts-12.pdf>.

${ }^{40} \mathrm{Ibid}$., at 34

${ }^{41}$ Ibid., at 30

${ }^{42}$ See FAO Code, n. 14 above, Article 9.2.2.
}

๑) 2007 The Authors. Journal compilation @ 2007 Blackwell Publishing Ltd. ecosystems; and establish appropriate mechanisms to facilitate cooperation on planning for aquaculture development including at the sub-regional and regional levels..$^{43}$ The Code also urges States to promote responsible development/management of aquaculture through advance evaluation of the effects of aquaculture development on genetic diversity and ecosystem integrity. ${ }^{44}$

The Technical Guidelines on Aquaculture Development, based on the Code ${ }^{45}$ note the need to establish predetermined standards, that is, acceptable limits of impacts, and recognize the special difficulty of setting standards for allowable genetic 'effluent'. ${ }^{46}$ However, difficulties arise in applying this guideline because of the scarcity of information on the effects of aquaculture/ wild animal interaction, survival of aquaculture escapees and their impact on ecosystems. ${ }^{47}$

\section{REGIONAL COORDINATES}

North Atlantic While the Convention for the Conservation of Salmon in the North Atlantic Ocean (NASCO Convention $)^{48}$ is aimed at minimizing the harvest in one Member State of salmon originating in another Member State ${ }^{49}$ the convention also leaves room for NASCO to act as a forum for consultation and cooperation in addressing the various environmental threats to wild salmon, including risks from aquaculture..$^{50}$ The main documentary vehicle for tackling aquaculture impacts is the Williamsburg Resolution, adopted at the twentieth annual meeting of NASCO in June 2003, and further amended at the twenty-first annual meeting in June $2004^{51}$ and twenty-third annual meeting in June 2006. ${ }^{52}$ The Resolution to Minimize Impacts from

\footnotetext{
${ }^{43}$ Ibid., Article 9.2.4.

${ }^{44}$ Ibid., Article 9.1.2.

${ }^{45}$ FAO Fisheries Department, Aquaculture Development, FAO Technical Guidelines for Responsible Fisheries, No 5 (FAO, 1997) ('FAO Technical Guidelines'), available at <http://www.fao.org/ DOCREP/003/W4493E/w4493e00.htm>.

${ }^{46}$ Ibid., at 10 , Box 3.

${ }^{47}$ Ibid.

${ }^{48}$ Convention for the Conservation of Salmon in the North Atlantic Ocean (Reykjavik, 2 March 1982), available at <http://www.nasco.org.uk/ pdf/nasco_convention.pdf>.

${ }^{49} \mathrm{lbid}$., Articles 7(1)(b)(c) and 8(b).

${ }^{50} \mathrm{lbid}$., Article 4(1)(b), which provides that one of the functions of NASCO's Council is 'to provide a forum for consultation and cooperation on matters concerning the salmon stocks in the North Atlantic Ocean beyond Commission areas . .

${ }^{51}$ See $\mathrm{n} .15$ above. For a brief history of aquaculture guidelines first adopted in 1991 and replaced later by the Oslo Resolution, which in turn was replaced by the Williamsburg Resolution, see L.P. Hansen and M.L. Windsor, 'Interactions between Aquaculture and Wild Stocks of Atlantic Salmon and other Diadromous Fish Species: Science and Management, Challenges and Solutions', 63:7 ICES Journal of Marine Science (2006), 1159.

${ }^{52}$ See Report of the Twenty-Third Meeting, n. 5 above, Annex 15, 'Report of the "Next Steps for NASCO" Task Force' (CNL(06)16), at 7, and Annex 20, 'Amendments to the "Williamsburg Resolution"' (CNL(06)18).
} 
Aquaculture, Introductions and Transfers, and Trangenics on the Wild Salmon Stocks not only urges parties to apply the precautionary approach to proposed aquaculture activities, ${ }^{53}$ but also calls upon them to minimize escapes of farmed salmon to a level that is as close as practicable to zero through the development and implementation of action plans as envisaged under the Guidelines on Containment of Farm Salmon adopted in $2001 .^{54}$ The resolution also urges parties to prohibit the introduction into any Commission area of viable nonindigenous anadromous salmonids or their gametes. ${ }^{55}$ Each party is asked to report annually to NASCO on measures/actions taken to implement key components for the resolution, including escape-minimization efforts and mitigation measures, such as contingency planning, to safeguard against potential impacts of aquaculture operations. ${ }^{56}$

The NASCO Guidelines, included as Annex 3 to the Williamsburg Resolution, provide only very general guidance to prevent escapes of farmed salmon. ${ }^{57}$ For example, Section 4.1 calls for nets, cages and mooring systems to be 'designed, constructed and developed to prevent escapes, having proper regard to the prevailing conditions at the site'. Section 5.2 urges that procedures 'be adopted to ensure that escapes are prevented during movement and handling of stocks (e.g. during stocking, counting, grading, transport, transfers, treatment and harvesting of fish), and during net changes and cleaning . . . A After each storm, all nets, cages and mooring systems should be subject to damage inspection ${ }^{58}$ and security systems are advocated to deter acts of vandalism. ${ }^{59}$ The guidelines call upon operators to report significant escapes and to develop contingency plans for such events. ${ }^{60}$ Each jurisdiction is urged to draw up a national action plan (or regional plans) for implementing the containment guidelines. ${ }^{61}$

The North American Commission Protocols for the Introduction and Transfer of Salmonids ${ }^{62}$ include a fundamental prohibition relating to potential salmon escapes. Reproductively viable strains of Atlantic salmon of European, including Icelandic, origin are

\footnotetext{
${ }^{53}$ See Article 3 of the Williamsburg Resolution, n. 15 above, which deals with the burden of proof. It provides that: 'Each Party, in accordance with the Precautionary Approach, should require the proponent of an activity covered by this Resolution to provide the information necessary to demonstrate that the proposed activity will not have a significant adverse impact on wild salmon stocks or lead to irreversible change'. The 2006 amendments inserted 'significant adverse impact' in place of 'an adverse impact'; ibid.

${ }^{54}$ Williamsburg Resolution, ibid., Article 15.

${ }^{55}$ Ibid.

${ }^{56}$ Ibid., Article 10.

${ }^{57}$ See NASCO Guidelines, n. 15 above.

${ }^{58} \mathrm{Ibid}$, at Section 5.6.

${ }^{59} \mathrm{lbid}$., at Section 5.8 .

${ }^{60} \mathrm{lbid}$., at Sections 6.2 and 6.3.

${ }^{61}$ Ibid., at Section 7.1 .

${ }^{62}$ Attached as Appendix 1 of the Williamsburg Resolution, n. 15 above.
}

not to be used in aquaculture in the North American Commission Area. ${ }^{63}$

Although having potential to address aquaculture escape issues, the Gulf of Maine Council on the Marine Environment, established pursuant to a State-provincial agreement in $1989,{ }^{64}$ has yet to do so. The Council prepared a Compendium of Federal, Provincial and State Regulatory Controls, Policies and Issues related to aquaculture in $1999,{ }^{65}$ but the publication included no recommendations on escapes. An Aquaculture Committee of the Council was in fact discontinued. ${ }^{66}$ The Gulf of Maine Council's Action Plan 2001-2006 ${ }^{67}$ does not directly address aquaculture operations, and a draft Action Plan 2006-2011 only suggests addressing bivalve shellfish aquaculture. ${ }^{68}$

North Pacific Two treaty regimes, aimed at conserving wild salmon in the North Pacific, have to date not focused on preventing escapes of farmed salmon. The Pacific Salmon Commission (PSC), established by the governments of Canada and the USA to implement the PST, does not have any programmes underway concerning farmed salmon as the parties have agreed that the problems will be dealt with in another forum or by governments directly. ${ }^{69}$ The North Pacific Anadromous

\footnotetext{
${ }^{63}$ Ibid., at Section 3.1(1).

${ }^{64}$ Agreement on Conservation of the Marine Environment of the Gulf of Maine between the Governments of the Bordering States and Provinces (Portland, Maine, 12 December 1989), reprinted in the Gulf of Maine Council on the Marine Environment, Gulf of Maine Action Plan 1991-2000, Appendix. Governors and premiers reaffirmed their commitment to the wise use of the Gulf of Maine and its watershed in a resolution included in the Gulf of Maine Council's Action Plan 20012006 (2002), at 6, available at <http://www.gulfofmaine.org/council/ action_plan/action_plan2001-06.pdf>.

${ }^{65}$ W.J. Brennan, Aquaculture in the Gulf of Maine: A Compendium of Federal, Provincial and State Regulatory Controls, Policies and Issues (Gulf of Maine Council on the Marine Environment, 1999).

${ }^{66}$ The Aquaculture Committee, established in 1998 to facilitate sharing of information and provide recommendations for sustainable aquaculture in the Gulf of Maine, was abolished in 2002. See P. Hinch, 'Appendix 2: Chapter 7 - Background Information on Groups', in G.G. Pesch and P.G. Wells (eds), Tides of Change Across the Gulf: An Environmental Report on the Gulf of Maine and Bay of Fundy (Gulf of Maine Council on the Marine Environment and the Global Programme of Action Coalition for the Gulf of Maine, 2004), at 138. ${ }^{67}$ See n. 64 above.

${ }^{68}$ See Gulf of Maine Council on the Marine Environment, Action Plan 2006-2011 'First Look Bringing-lt-Together Draft' (June 2006), available at $<$ http://www.gulfofmaine.org/council/internal/>. The draft plan suggests developing a 3-year Gulf-wide strategy for enhancing sustainability in the wild and aquaculture bivalve shellfish industry including the application of best management practices within the industry. The draft does call for accelerated regional cooperation on invasive species minimization and prevention efforts and, after the Action Plan is finalized, it is possible that the Northeast Aquatic Nuisance Species Panel, having State (Maine, New Hampshire, Vermont, Massachusetts, Rhode Island, Connecticut and New York) and provincial (Quebec, New Brunswick and Nova Scotia) membership, could work with a re-constituted council aquaculture group to address escapee issues.

${ }^{69}$ Personal correspondence between T. Barry and D. Kowal, Executive Secretary of the PSC (12 November 2003).
} 
Fish Commission (NPAFC), operating under the Convention for the Conservation of Anadromous Stocks in the North Pacific Ocean, has not included the effects of the aquaculture within its mandate. ${ }^{70}$

Efforts by BC and Washington State to enhance transboundary environmental cooperation have also sidestepped aquaculture escape issues. The $\mathrm{BC} /$ Washington Environmental Cooperation Agreement, which established a Council in 1992 to ensure coordinated action and information sharing, ${ }^{71}$ has not addressed the issue of escaped salmon directly. ${ }^{72}$ In 2000, a BC-Washington State Letter of Understanding Regarding Salmon Escape Reduction was drafted with the objective to promote cooperation through information sharing on prevention planning, reporting of farmed salmon escapes, escape response and recovery, and research. ${ }^{73}$ However, the Washington Bill to implement the understanding was never approved due to funding issues and has not been revitalized. ${ }^{74}$

A sub-regional programme on the Canadian west coast is the Atlantic Salmon Watch Program (ASWP). Initiated in 1991 by the Department of Fisheries and Oceans in $\mathrm{BC}$ as a joint federal and provincial programme, ASWP monitors the abundance, distribution and biology of escaped Atlantic salmon in North Pacific waters. However, there is little work devoted to assigning a country of origin to escapes, making ASWP primarily an informative instrument with no enforcement provisions or guidelines to prevent escapes. ${ }^{75}$ ASWP also works with State agencies in Alaska and Washington State but there is no formal agreement with regards to reporting escapes. ${ }^{76}$

\section{DIVERGENT REGULATORY CURRENTS}

As a result of the limited global and regional coordinates addressing the regulation of aquaculture escapes, divergent

\footnotetext{
${ }^{70}$ Personal correspondence between T. Barry and Y. Kondo, NPAFC Secretariat (13 November 2003). Also see, generally, North Pacific Anadromous Fish Commission, Short Description of the NPAFC (North Pacific Anadromous Fish Commission, March 2006), available at $<$ http://www.npafc.org/short_description/short.html>.

${ }^{71}$ See ECA, n. 18 above.

${ }^{72}$ C.R. Berris, 'Siting of Salmon Farms', Salmon Aquaculture Review (31 January 1997), available at <http://www.eao.gov.bc.ca/PROJECTS/ AQUACULT/SALMON/Reports/ tat/Siting.HTM>.

${ }^{73}$ B. Nohr, Aquaculture Research and Development Officer, BC Ministry of Agriculture, Food and Fisheries, email correspondence with T. Barry (2 December 2004). Personal correspondence between T. Barry and C. Townsend, Research and Policy Advisor, BC Ministry of Agriculture, Food and Fisheries, Aquaculture Development Branch (17 November 2003).

${ }^{74}$ See B. Nohr, n. 73 above

${ }^{75}$ Fisheries and Oceans Canada, Atlantic Salmon Watch Program (DFO, June 2006), available at <http://www.pac.dfo-mpo.gc.ca/sci/ aqualASWP_e.htm>

${ }^{76}$ Personal correspondence between T. Barry and A. Thomson, Aquaculture Coordinator - Pacific Region Fisheries and Oceans Canada (19 July 2006).
}

regulatory approaches exist in jurisdictions along the North Atlantic and North Pacific coastlines. In fact, each jurisdiction reviewed employs a different regulatory approach to addressing the issue of escapes. The approaches of Canada, the Atlantic provinces and BC are first discussed, followed by a review of US, State of Maine, Washington and Alaska approaches to preventing escapes.

\section{THE APPROACH TO AQUACULTURE REGULATION IN CANADA}

Due to the constitutional divide in Canada, both the federal and provincial governments have regulatory responsibility over aquaculture. ${ }^{77}$ Federally, the lead department for dealing with the aquaculture industry in Canada is the Department of Fisheries and Oceans (DFO).$^{78}$ A number of federal statutes may apply to aquaculture; however, none directly regulate escapes. One such statute is the Oceans Act, which promotes integrated coastal area management and ecosystem-based management. ${ }^{79}$ One aspect of the Act that could address escapes is Part II on Oceans Management Strategy, specifically Sections 29 and 31, which speak of a national strategy for the management of marine ecosystems and for the integrated management of activities affecting marine ecosystems. ${ }^{80}$ However, while the strategy mentions the precautionary principle, it only generally discusses regulation and its current effect on aquaculture is minimal. ${ }^{81}$

The Fisheries Act is arguably Canada's strongest legislative means of protecting the marine environment, and the basis for DFO's role in setting aquaculture authorization conditions and reviewing licence applications. ${ }^{82}$

\footnotetext{
${ }^{77}$ The constitutional role for the federal government, in relation to aquaculture, is set out in Section 91 of the Constitution Act 1867, as the responsibility for sea coast and inland fisheries, shipping and development, trade and commerce, inter-provincial/international waters, Indians and Indian reserves, and federal works and undertakings. The provinces have constitutional authority over property and civil rights in relation to aquaculture under Section 92. See Constitution Act 1867 (UK), 30 \& 31 Vict., c. 3, reprinted in (1985) R.S.C. App. II, No 5. ${ }^{78}$ Other federal departments involved are the Canadian Coast Guard, the Canadian Food Inspection Agency, Environment Canada and the Pest Management Regulatory Agency under the Department of Health. See W.J. Brennan, n. 65 above.

${ }^{79}$ Oceans Act, S.C. 1996 , c. 31.

${ }^{80}$ Government of Canada, Department of Fisheries and Oceans, Canada's Oceans Management Strategy: Our Oceans, Our Future (Fisheries and Oceans Canada, 2002), available at <http:// www.cos-soc.gc.ca/doc/cos-soc/message_e.asp>.

${ }^{81}$ D. VanderZwaag et al., 'Canadian Aquaculture and the Principles of Sustainable Development: Gauging the Law and Policy Tides and Charting a Course - Part II', 28 Queen's L.J. (2003), 529, at 579.

${ }^{82}$ Fisheries Act, R.S. 1985, c. F-14, Section 1. Two regulations under the Fisheries Act apply to aquaculture but do not regulate escapes. The first is the Fish Health Protection Regulations, C.R.C., c. 812, which requires permits for the importation of cultured fish across provincial or international borders. The second is the Fisheries (General) Regulation, SOR/93-53, which requires a licence for the release and transfer of live fish under Part VIII.
} 
Section 35 of the Act, prohibits works or undertakings that result in the harmful alteration, disruption or destruction of fish habitat unless authorized by the Minister of DFO. Section 36(3) prohibits the deposit of a deleterious substance of any type in water frequented by fish, and establishes DFO's role to protect and conserve wild fish and their habitat. ${ }^{83}$ If escapes were considered a 'deleterious substance' under the Act, escape events could result in a violation of Section 36(3). ${ }^{84}$ As of yet, escapes have not been regulated under the Act. Moreover, the Auditor General of Canada observed in 2000 that DFO was not carrying out its regulatory responsibilities under the Act to protect salmon stocks from the effects of aquaculture. ${ }^{85}$

The Species at Risk Act (SARA) ${ }^{86}$ has potential to spur the addressing of escapes through recovery strategy and action plan requirements in relation to listed threatened or endangered species. This possible role for SARA currently only relates to the Inner Bay of Fundy Atlantic salmon populations, which are listed under SARA as endangered, as the Pacific species, including Cultus and Sakinaw Lake sockeye salmon, are not listed ${ }^{87}$ Recovery strategies are required to include an identification of threats to the survival of species, while action plans are required to identify measures proposed to protect species' critical habitat and measures

\footnotetext{
${ }^{83} \mathrm{Ibid}$.

${ }^{84}$ Ibid., Section 34(1). 'Deleterious substance' is defined, as 'any substance that, if added to any water, would degrade or alter or form part of a process of degradation or alteration of the quality of that water so that it is rendered or is likely to be rendered deleterious to fish or fish habitat or to the use by man of fish that frequent that water'. Well-known organizations, such as the David Suzuki Foundation, believe that the escapes are a violation of the deleterious substance provision in Section 36(3) of the Fisheries Act. See O.E. Langer, Is there a Bottom Line in the Wild Salmon Farmed Salmon Debate? A Technical Opinion (David Suzuki Foundation, March 2003) available at <http://www.davidsuzuki.org/ files/Oceans/March03Ottotechnicalpaper.pdf>.

${ }^{85}$ R.C. Thompson, 'Fisheries and Oceans - The Effects of Salmon Farming in British Columbia of the Management of Wild Salmon Stocks', 2000 Report of the Auditor General of Canada, chapter 30 (Office of the Auditor-General of Canada, December 2000), available at <http://www.oag-bvg.gc.ca/domino/reports.nsf/html/0030ce.html>. See also D. VanderZwaag, G. Chao and M. Covan, 'Canadian Aquaculture and the Principles of Sustainable Development: Gauging the Law and Policy Tides and Charting a Course', 28 Queen's L.J. (2002), 279, at 304.

${ }^{86}$ Species at Risk Act, S.C. 2002, c. 29. For a detailed critique of SARA, see D.L. VanderZwaag and J.A. Hutchings, 'Canada's Marine Species at Risk: Science and Law at the Helm, But a Sea of Uncertainties', 36:2 Ocean Development \& International Law (2005), 219

${ }^{87}$ See the Species at Risk Act Public Registry for information on the status of the Inner Bay of Fundy Atlantic Salmon, available at $<$ http://www.sararegistry.gc.ca/default_e.cfm>. The Committee on the Status of Endangered Wildlife in Canada (COSEWIC) has listed the Pacific species of Cultus and Sakinaw Lake sockeye salmon as endangered. See Environment Canada, Sockeye Salmon, Cultus Populations (Environment Canada, May 2003), available at <http:// www.speciesatrisk.gc.ca/search/speciesDetails_e.cfm?SpeciesID=730>.
}

to implement the recovery strategy. ${ }^{88}$ It remains to be seen how the SARA process will address escape issues. A SARA-compliant recovery strategy for Inner Bay of Fundy Atlantic Salmon was targeted for sign-off by the competent Ministers by 31 December $2006^{89}$ and an action plan has yet to be prepared.

Recent federal initiatives such as the Wild Salmon Policy in BC, with the goal of restoring and maintaining healthy wild salmon populations, ${ }^{90}$ and the announcement of an Atlantic Wild Salmon Policy ${ }^{91}$ and a CAN\$30 million investment in the Atlantic Salmon Endowment Fund, ${ }^{92}$ offer windows to address aquaculture escape prevention in efforts to conserve wild salmon. While it is too soon to judge definitively the utility of these policies in relation to addressing escape management issues, the current language in BC's policy makes no specific commitment to deal with escapes. ${ }^{93}$

\section{REGULATION OF ESCAPES ALONG EASTERN CANADA'S COASTLINE}

The authority over the fish farming industry in Nova Scotia, New Brunswick, and Newfoundland and Labrador has been delegated to the provincial governments through Memoranda of Understanding (MOUs) with the

${ }^{88}$ See the Species at Risk Act Public Registry for information on the development of a recovery strategy and action plan for a listed species, available at <http://www.sararegistry.gc.ca/plans/default_e.cfm>. See also Department of Fisheries and Oceans Canada, Species at Risk: What the Act Means to You (DFO, 28 September 2006), available at $<$ http://www.dfo-mpo.gc.ca/species-especes/actMeans/actMeans_e.asp>.

${ }^{89}$ See Response Statements - Atlantic Salmon (29 November 2006), available at <http://www.strategy.gc.ca/status/showHTML_e.cfm? ocid $=4752>$

90 The Wild Salmon Policy for Pacific salmon was initiated in 2000 and underwent 5 years of public review before adoption in June 2005. See Fisheries and Oceans Canada, 'Adoption of Wild Salmon Policy Continues Reform of Pacific Fisheries', News Release (24 June 2005), available at <http://www.pac.dfo-mpo.gc.ca/comm/pages/release/preleas/2005/nr047_e.htm>

${ }^{91}$ Fisheries and Oceans Canada, 'Consultations to Begin on Wild Salmon Policy', News Release (17 December 2004), available at <http://www.pac.dfo-mpo.gc.ca/comm/pages/release/p-releas/2004/ nr073_e.htm>.

${ }^{92}$ See Fisheries and Oceans Canada, 'Speaking Notes for Geoff Regan, Minister of Fisheries and Oceans: Atlantic Salmon Endowment Fund', Media Room Minister's Speeches (28 February 2005), available at <http://www.dfo-mpo.gc.ca/media/speech/2005/20050228_e.htm>. The Minster of DFO announced, on 18 November 2006, that the Atlantic Salmon Endowment Fund, established in 2005, will receive CAN\$30 million to assist projects that contribute to restoring and conserving salmon population in rivers in the Atlantic provinces and Quebec'. See Department of Fisheries and Oceans Canada, 'Canada's New Government Invests \$30M in the Establishment of the Atlantic Salmon Endowment Fund', News Release (18 November 2006), available at <http://www.dfo-mpo.gc.ca/media/newsrel/2006/hqac42_e.htm?template=print>

${ }^{93}$ Fisheries and Oceans Canada, Canada's Policy for Conservation of Wild Pacific Salmon (Fisheries and Oceans Canada, 2005), at 31, available at <http://www-comm.pac.dfo-mpo.gc.ca/publications/ wsp/wsp_e.pdf>. 
government of Canada. ${ }^{94}$ All MOUs in these provinces address the responsibility for ensuring compliance with federal legislation and monitoring the health of caged stock. The responsibility for inspecting farms is either delegated to the province or jointly undertaken..$^{95}$ Currently, only Newfoundland and Labrador has an enforceable containment code aimed at limiting escape events. Regulation of the aquaculure industry in Prince Edward Island (PEI) will not be reviewed in this article because currently the industry only consists of land-based freshwater salmon hatcheries, due to divergent marine water temperatures between seasons. ${ }^{96}$

Nova Scotia The Nova Scotia Department of Fisheries and Aquaculture is the lead provincial agency for aquaculture under the province's Fisheries and Coastal Resources Act. ${ }^{97}$ At present, the only avenue to regulate escapes is under Section 56 of the Act, which gives the Minister the authority to impose conditions on the conduct of aquaculture, and Section 64, which gives the government the ability to place conditions on licences relating to enclosures. ${ }^{98}$ This authority has not been exercised to make consistent licensing conditions that require measures to prevent escapes, standards for net or cage structure, auditing requirements or escape reporting. Any such licensing conditions relating to escapes are thus applied on a case-by-case basis. ${ }^{99}$

The aquaculture industry has taken positive steps to address the issue of escapes in Nova Scotia. The Aquaculture Association of Nova Scotia (AANS) developed the Aquaculture Environmental Management Guidelines in 2000, which included a draft code of containment. ${ }^{100}$ However, the code was left for 6 years in draft format and was ultimately abandoned by AANS. Instead, AANS intends to adopt the New Brunswick Code of Containment currently under development. ${ }^{101}$

\footnotetext{
${ }^{94}$ See D. VanderZwaag et al., n. 81 above, at 532-534.

${ }^{95}$ Ibid., at 533-534.

${ }^{96}$ Personal correspondence between T. Barry and R. Gallant, Acting Director of PEI Department of Agriculture, Fisheries and Aquaculture (19 December 2006).

${ }^{97}$ Fisheries and Coastal Resources Act, S.N.S. 1996, c. 25, Section 1. ${ }^{98}$ Ibid., at Sections 56 and 64.

${ }^{99}$ Personal correspondence between T. Barry and T. Balch, Manager of Aquaculture Development, Aquaculture Division of the Department of Fisheries and Aquaculture (17 July 2006). An example of case-bycase application is Licence No 1169 between the Province of Nova Scotia and Aquafish Technology Inc. (18 October 2001), at Schedule B. In this, licence approval is subject to a number of provisions, one of which is the reporting of escapes.

${ }^{100}$ See generally the website for the Aquaculture Association of Nova Scotia, available at <http://www.aansonline.com/info/index.html>. Aquaculture Association of Nova Scotia, 'Section B: Finfish Aquaculture Operations', Aquaculture Environmental Management Guidelines (draft version, 2004), provided through personal correspondence between T. Barry and B. Muise, Executive Director of the Aquaculture Association of Nova Scotia (26 October 2004).

${ }^{101}$ Personal correspondence between T. Barry and B. Muise, Executive Director of the Aquaculture Association of Nova Scotia (19 July 2006).
}

New Brunswick In New Brunswick, the most productive maritime salmon farming jurisdiction, there are currently no escape prevention regulations. ${ }^{102}$ As the province closest to Maine, New Brunswick will likely face the most pressure regarding any international issues concerning escaped salmon on the east coast of Canada. ${ }^{103}$ The Department of Agriculture, Fisheries and Aquaculture (DAFA) is the primary provincial agency responsible for aquaculture in New Brunswick and enforces the province's Aquaculture Act. ${ }^{104}$ The provincial government has the authority to make licences subject to conditions aimed at preventing escapes under Section 11 of the Aquaculture Act. ${ }^{105}$ Currently, there are no containment or auditing standards in licences and reporting is not mandatory. ${ }^{106}$

DAFA has contracted an industry organization, the New Brunswick Salmon Growers Association (NSBGA), to finalize a draft Code of Containment. ${ }^{107}$ The expected completion date for the code is March 2007. ${ }^{108}$ It is unknown at this point how the containment code will be enforced or whether compliance with the code will be a licensing requirement. ${ }^{109}$

Newfoundland and Labrador The Newfoundland and Labrador Department of Fisheries and Aquaculture (NFDFA) is the province's lead aquaculture agency and administers that province's Aquaculture Act. ${ }^{110}$ The Act allows inspections where escapes may be a threat or proponents are not meeting licensing conditions. ${ }^{111}$ Section 56 of the Act also permits inspectors to direct a licensee to take measures to prevent escapes.

Newfoundland was the first province to implement a containment code. ${ }^{112}$ The code was developed by NFDFA and the Newfoundland Salmonid Growers Association

\footnotetext{
102 In 2001, New Brunswick produced 32\% of Canada's total production of farmed Atlantic salmon. See New Brunswick Salmon Growers Association, About the Industry (NBSGA, 2004), available at <http://www.nbsga.com/industry.html>.

${ }^{103}$ Personal correspondence with M. Kesselring, Regulatory Compliance Manager for Stolt Sea Farm's East Coast Operations in Maine and New Brunswick (12 November 2003).

${ }^{104}$ Aquaculture Act, S.N.B. 1988, c. A-9.2, Section 28.

105 Ibid., at Section 11(1).

${ }^{106}$ Personal correspondence between T. Barry and K. Lipsett, Director of Sustainable Aquaculture and Fish Health in the Department of Agriculture, Fisheries and Aquaculture (20 July 2006).

${ }^{107}$ Ibid.

${ }^{108}$ Personal correspondence between T. Barry and Dr J. Smith, Environmental Management and Research Coordinator with New Brunswick Salmon Growers Association (27 July 2006). See also NBSGA Environmental Policy and Codes of Practice, Version 1.0 (NBSGA, June 2004), available at <http://www.nbsga.com/science.html>. ${ }^{109}$ Ibid.

${ }^{110}$ Aquaculture Act, R.S.N.L. 1990, c. A-13

111 Ibid., at Section 6(3)(b).

${ }^{112}$ See Code of Containment for the Culture of Salmonids in Newfoundland and Labrador (February 2005), received through personal correspondence between T. Barry and the Newfoundland Salmon Grower's Association (12 July 2006).
} 
(NSGA) in 1999, and addresses equipment standards, moorings, ice protection, system inspection, handling standards, predator control, inventory monitoring and recapture methods. ${ }^{113}$ The code requires farms to report net testing results to NFDFA, to have recapture plans (Appendix 7) and to report any escape events to DFO. ${ }^{114}$

Section 4(5) of the Act makes adherence to the code a licensing condition and, thus, a violation of the code is a violation of the licence. ${ }^{115}$ The integration of code and licensing requirements makes penalties under Section 14 of the Act available for violations of the code.

\section{REGULATION OF ESCAPES IN BC}

The issue of aquaculture escapes is contentious in BC because, among other reasons, it has the most extensive aquaculture operations in Canada, ${ }^{116}$ and the common species farmed are Atlantic and, therefore, 'exotic' species. These factors led to a moratorium on aquaculture production from 1995 to 2002. Consequently, $\mathrm{BC}$ is the province with the most research, policy and regulations dedicated to addressing escapes.

Provincial control over aquaculture is carried out through the Land Act, ${ }^{117}$ Fisheries Act (BC) ${ }^{118}$ and the Environmental Management Act. ${ }^{119}$ Aquaculture facilities in BC require a licence issued by the Fisheries and Aquaculture Licensing and Compliance Branch of the provincial Ministry of Agriculture and Lands. ${ }^{120}$

In 1997, the provincial government funded the Salmon Aquaculture Review (SAR), ${ }^{121}$ which identified a range of research needs associated with the industry, investigated aquaculture effects on the environment and wild salmon, and made 49 recommendations to the province. ${ }^{122}$

\footnotetext{
${ }^{113}$ Personal Correspondence between T. Barry and G. Perry, Regional Aquaculture Coordinator and Chair of the Regional Aquaculture Collaborative Research and Development Program in Newfoundland (3 November 2004).

${ }^{114}$ See Code of Containment, n. 112 above, at Appendix A1.1, Appendix 7 and Annex 1.

115 Ibid., Section 4(5). Personal correspondence between T. Barry and E. Barlow, Aquaculture Branch of the Department of Fisheries and Aquaculture (14 July 2006)

${ }^{116}$ For example, in 2003 , there were 128 salmon farms along the coast from the Strait of Georgia to Bella Bella. Statistic provided through personal correspondence with A. Thomson, Senior Aquaculture Officers - Pacific Region Fisheries and Oceans Canada (12 November 2003).

117 Land Act, R.S.B.C. 1996 , c. 245.

${ }^{118}$ Fisheries Act, R.S.B.C. 1996, c. 149.

${ }^{119}$ Environmental Management Act, R.S.B.C. 2003, c. 53. See also British Columbia Environmental Assessment Office, 'Existing Salmon Aquaculture Management Systems in BC', Salmon Aquaculture Review (BCEAO, 26 August 1997), chapter 3, available at <http:// www.eao.gov.bc.ca/epic/output/html/deploy/epic_project_doc_list_20_r_ com.html>.

${ }^{120}$ See Fisheries Act, n. 118 above, at Sections 13 and 16.

${ }^{121}$ Ibid.

${ }^{122}$ See British Columbia Environmental Assessment Office, n. 119 above.

๑ 2007 The Authors. Journal compilation @ 2007 Blackwell Publishing Ltd.
}

One of these recommendations was for containment and prevention regulations. ${ }^{123}$

In 2002, the province established licensing conditions relating to escapes in the Aquaculture Regulation. ${ }^{124}$ Section 3(1) of the regulation prohibits the release of finfish from aquaculture, unless authorized to do this by an aquaculture licence, and Section 3(2) and (3) require a licence holder to take 'reasonable precautions' to prevent escapes and 'all reasonable measures' to mitigate the effect of escapes. ${ }^{125}$ Licence holders are required to keep inspection and maintenance records, and report escape events. ${ }^{126}$

Appendix 2 of the Aquaculture Regulation establishes standards of practice for escape prevention and response. Part I of Appendix 2 relates to equipment design, use and maintenance, and sets minimum requirements for containment structures, net cages and record keeping. ${ }^{127}$ A licence holder must also develop and follow a 'best available management practices plan' under Part II, and create an 'escape prevention plan' under Part III. ${ }^{128}$ The Regulation is enforced under Section 29(1) of the Act, which allows a fine of not less than CAN\$100 and not more than CAN\$10,000 for violations. ${ }^{129}$

Various weaknesses of the Aquaculture Regulation stand out. They include the fact that the regulation bases its standards on those 'generally accepted' in the industry, granting industry discretion when developing best management plans, and the absence of a regular auditing requirement.

The BC Salmon Farmers Association (BCSFA) developed a Code of Practice for its members. ${ }^{130}$ The compliance

\footnotetext{
${ }^{123}$ See 2000 Report of the Auditory General of Canada, n. 85 above.

${ }^{124}$ Aquaculture Regulation, B.C.Reg 78/2002, O.C.283/2002.

125 Ibid., Section 3.

${ }^{126} \mathrm{Ibid}$., Sections 4(1) and 6(1).

${ }^{127}$ Part I(A) requires generally that equipment and structures be designed and maintained in a manner that prevents escapes. Part I(B) details more specifically the requirements for containment structures, cage support systems and anchoring equipment, while (C) deals with net cage requirements and creates minimum breaking strength standards for net mesh.

${ }^{128}$ See Aquaculture Regulation, n. 124 above, Appendix 2. Section 34 of Part II requires licence holders to develop and follow a best management practices plan, which is consistent with the standards established in Appendix 2. Part III requires escape response plans that must contain a step-by-step procedure for preventing further escapes and reporting escapes, and the holder must take immediate corrective action after an escape event.

${ }^{129}$ Ministry of Agriculture and Lands, Escape Prevention in British Columbia (Government of British Columbia, 30 December 2003), available at <http://www.agf.gov.bc.ca/fisheries/escape/escape_prevention.htm>. See also Fisheries Act, n. 118 above, Section 25.

${ }^{130}$ BC Salmon Farmers Association, Code of Practice (BC Salmon Farmers Association, 24 November 2003), available at <http:// www.salmonfarmers.org/files/code_of_practice.html>. With respect specifically to membership, producers include Creative Salmon, Greig Seafood BC Ltd, Marine Harvest, Mainstream Canada, Omega Pacific Hatchery Inc., Pan Fish Canada, Sea Spring Salmon Farm Ltd, Target Marine Products LLP and West Coast Fish Culture Ltd. See the website available at <http://www.salmonfarmers.org/files/ members1.html>.
} 
committee, made up of three BCSFA members and two public interest representatives appointed by the board of directors of the BCSFA, can investigate for compliance and report to the board of directors, who can subsequently penalize a member for breaches of the code. Stock containment is dealt with in Part 8 of the code, which creates standards for fish handling, worker training, a fish escape plan, equipment, net cage strength, boat operations, equipment monitoring and transportation. ${ }^{131}$ Equipment must meet the accepted industry standards and 'ensure the containment of farm stocks', but the code says nothing about meeting best management practices or developing new technology. The code may have stricter requirements than the provincial regulations, but its usefulness has been questioned because other stakeholders were not consulted during the code's development. ${ }^{132}$

The $\mathrm{BC}$ judiciary passed up an opportunity to shape the direction of escapes regulation in Homalco Indian Band $v$. British Columbia (Minister of Agriculture, Food and Fisheries). ${ }^{133}$ The Homalco Indian Band sought judicial review of a governmental decision to approve amendments to an existing fish farm licence allowing the farming of Atlantic salmon in their traditional territory. The Holmaco argued that the amendment was granted without adequate consultation or accommodation of their concerns, one of which was the adverse impact of escapes on their Aboriginal right to harvest wild salmon.

The Holmaco alleged that the minister approving the licence amendment failed to consider properly the potential risk of escapes and failed to apply the precautionary approach. Even though the trial judge accepted that the risk of escapes was uncertain and that more research was required, ${ }^{134}$ he relied on the Crown's argument that the current regulatory scheme was precautionary enough. The trial judge adjourned the application to allow continued consultation and refused to grant an injunction preventing the company from stocking Atlantic salmon without a DFO permit that authorized the alleged harmful alteration, disruption or destruction of fish habitat pursuant to Section 35(2) of the Fisheries Act. ${ }^{135}$

\footnotetext{
${ }^{131}$ See BC Salmon Farmers Association, ibid., Part 8.

${ }^{132}$ Georgia Strait Alliance for the Coastal Alliance of Aquaculture Reform, Regulating Salmon Aquaculture in BC - A Report Card (Georgia Strait Alliance for the Coastal Alliance of Aquaculture Reform, 2004), at 59, available at <http://www.georgiastrait.org/ BCFishFarmReport.php>.

${ }^{133}$ Homalco Indian Band v. British Columbia (Minister of Agriculture, Food and Fisheries) (2005) 39 BCLR (4th) 263 (BCSC).

${ }^{134}$ The Honourable Mr Justice Powers accepted the uncertainty of the risks caused by the escape of farmed Atlantic salmon, as follows at para. 34: 'However, what is clear from the material is that there are differences in scientific opinion about the effects and risks involved with salmon aquaculture, and particularly the farming of Atlantic salmon and its effect, or potential effect on wild salmon stocks. All of the scientists and panels involved in studying the issues confirm that there are serious gaps in knowledge and research is needed to fill those gaps'; ibid. ${ }^{135} \mathrm{Ibid}$., at paras. 139 and 148.

\section{THE APPROACH TO AQUACULTURE REGULATION IN THE USA}

In the USA, no single federal agency has the lead regulatory responsibility over aquaculture, causing a 'patchwork' of regulation under State and federal laws. ${ }^{136}$ In fact, there are around 17 federal departments and agencies involved ${ }^{137}$ making aquaculture one of the most regulated industries in the USA. ${ }^{138}$ Each State also has the authority to regulate aquaculture because they hold title to their tidal lands under navigable water in trust for the public. ${ }^{139}$ The number of regulatory bodies involved, however, does not necessarily amount to adequate regulation. ${ }^{140}$

The USA does have national-level aquaculture-specific legislation: the National Aquaculture Act 1980. ${ }^{141}$ The Act, which is administered by National Oceanic and Atmospheric Administration (NOAA), mainly describes the policy surrounding aquaculture, and its main purpose is clearly to promote development. ${ }^{142}$ Positive, and possibly useful, initiatives under the Act include the draft National Aquaculture Development Plan ${ }^{143}$ and the Joint Subcommittee on Aquaculture, ${ }^{144}$ which

\footnotetext{
${ }^{136} \mathrm{~J}$. Firestone, 'Offshore Marine Aquaculture in US federal Waters: Picking up the Pieces and Painting a Picture', in D.L. VanderZwaag and G. Chao (eds), Aquaculture Law and Policy: Towards Principled Access and Operations (Routledge, 2006), at 465.

${ }^{137}$ Aquaculture Network Information Center, United States Joint Subcommittee on Aquaculture, Guide to Federal Aquaculture Programs and Services (Aquaculture Network Information Center, 25 November 2006), available at <http://ag.ansc.purdue.edu/ aquanic/jsa/federal_guide/index.htm>. These federal agencies include the US Army Corps of Engineers, the Environmental Protection Agency, Health and Human Services Department, US States Department of the Interior, National Science Foundation, US Agency for International Development, Food and Drug Administration, US Department of Agriculture, the US Department of Commerce, the National Oceanic and Atmospheric Administration, the Department of Defense, Department of Energy, Small Business Administration and the Farm Credit Administration.

${ }^{138}$ H.D. McCoy, American and International Aquaculture Law (Supranational Publishing, 2000), at 247.

${ }^{139}$ See W.J. Brennan, n. 65 above.

${ }^{140}$ E.R. Englebrecht, 'Can Aquaculture Continue to Circumvent the Regulatory Net of the Magnuson-Stevens Fishery Conservation and Management Act?', 51 Emory L.J. (2002), 1187.

${ }^{141} \mathrm{M}$. Arsenault et al., Current and Future Regulation of Marine Aquaculture, Report submitted to Professor Susan Vernon-Gerstenfeld and Ronald R. Biederman of the Washington Project Center (12 December 2002), available at <http://www.lib.noaa.gov/docaqua/ wpiprojects/currentrept.htm>.

142 National Aquaculture Act 1980, 16 U.S.C. 2801, as amended.

${ }^{143}$ Aquaculture Network Information Center, Draft National Aquaculture Development Plan of 1996 Joint Subcommittee on Aquaculture National Science and Technology Council (Aquaculture Network Information Center, 1996), available at <http://aquanic.org/publicat/ govagen/usda/dnadp.htm>

${ }^{144}$ See, generally, United States Joint Subcommittee on Aquaculture Task Forces and Working Groups, National Aquaculture Science and Technology Task Force (US Joint Subcommittee on Aquaculture, 15 March 2005), available at <http://aquanic.org/jsa/ subcomit.htm>.
} 
deals with science and technology developments in aquaculture. These initiatives could address environmental aspects of the industry and balance the prodevelopment approach in the Act. ${ }^{145}$

NOAA, as the federal oceans agency with responsibility for the sustainable use and conservation of marine resources, monitors the regulation of marine aquaculture because of its effects on wild stocks. ${ }^{146}$ NOAA implements its role to create environmentally sound aquaculture policy in coordination with the National Marine Fisheries Service (NMFS), which assumes the regulatory role in the Exclusive Economic Zone, and the National Sea Grant College Program, which focuses on aquaculture research activities.

The Army Corps of Engineers (ACOE) is often viewed as the lead federal agency for regulating the aquaculture industry through Section 10 of the Rivers and Harbors Act, ${ }^{147}$ which requires permits for any obstruction in marine waters that may impede navigation. The ACOE is also obligated to consult with the National Marine Fisheries Service (NMFS) and US Fish and Wildlife Service (FWS) if a permit they grant may impact an endangered species. ${ }^{148}$ While the ACOE does have wide discretion in its permitting process, only in early 2005 did the ACOE begin to implement permit conditions for the prevention of escapes, and only in some States on the east coast. ${ }^{149}$

The US Environmental Protection Agency (EPA) regulates discharges from aquaculture facilities and, therefore, escapes under the Clean Water Act (CWA), ${ }^{150}$ because farms are considered 'concentrated aquatic animal production facilities' ${ }^{151}$ Under the CWA, National Pollution Discharge Elimination System (NPDES) permits are required for all marine aquaculture facilities but are issued based on different criteria in each State. ${ }^{152}$

Given the declaration of some US salmon stocks as endangered, the Endangered Species Act (ESA) ${ }^{153}$

\footnotetext{
${ }^{145}$ R.J. Rychlak and E.M. Peel, 'Swimming Past the Hook: Navigating Legal Obstacles in the Aquaculture Industry', 23 Environmental Law (1993), 837.

${ }^{146}$ Southwest Regional Office of the National Marine Fisheries Service, NOAA's Aquaculture Policy, available at <http://swr.ucsd.edu/ $\mathrm{fmd} / \mathrm{bill} / \mathrm{aquapol} . \mathrm{htm}>$.

${ }^{147}$ Rivers and Harbors Act 1899, 33 U.S.C. 403.

${ }^{148}$ See Southwest Regional Office, n. 146 above. See also Rivers and Harbors Act 1899, ibid., Section 10.

${ }^{149}$ D. Hopkins, R. Golburg and A. Marston, 'An Environmental Critique of Government Regulations and Policies for Open Ocean Aquaculture', 2:2 Ocean \& Coastal L.J. (1996), 235, at 241. This is discussed further under the heading of 'Regulation of Escapes in Maine'; personal correspondence between T. Barry and S. HornOlsen, Aquaculture Policy Coordinator for the Maine Department of Marine Resources (27 September 2006).

${ }^{150}$ Clean Water Act, 33 U.S.C. $\$ 1251$ et seq. (1977).

${ }^{151}$ See R.J. Rychlak and E.M. Peel, n. 145 above, at 853.

${ }^{152}$ See D. Hopkins, R. Golburg and A. Marston, n. 149 above, at 27.

${ }^{153}$ Endangered Species Act 1973, 16 U.S.C. §1531 et seq.

@ 2007 The Authors. Journal compilation (c) 2007 Blackwell Publishing Ltd.
}

requires federal agencies, such as the ACOE, NMFS and FWS, to utilize their regulatory authority to conserve listed species and ensure that marine operations, such as aquaculture, do not jeopardize survival. ${ }^{154}$ The ESA provides for the "prohibition of harm, mandatory habitat protection and has been referred to as the strongest environmental law in the world'. ${ }^{155}$ Recently, NOAA and FWS published a recovery plan for the endangered salmon population in the Gulf of Maine, which clearly acknowledges the harm caused by escapes by stating 'actions to minimize the potential interaction between wild and farmed fish should continue to receive a high priority for implementation'. ${ }^{156}$ However, no direct recommendations relating to escapes are made in the plan. Recovery plans under the ESA are also being developed for endangered salmon species on the west coast. ${ }^{157}$

Regulation of Escapes in Maine In Maine, both the federal and State government have authority over fisheries, marine mammals, navigation, fish health, and the protection of wild stocks and habitat. State regulatory control over aquaculture is under the Department of Marine Resources (DMR), which regulates aquaculture leasing, ${ }^{158}$ and the Department of Environmental Protection (DEP), which permits aquaculture facilities under the Maine Pollutant Discharge Elimination System General Permit for Atlantic Salmon Aquaculture (MePDES). ${ }^{159}$

Wild salmon populations are designated as endangered in eight rivers in Maine. ${ }^{160}$ This designation by the FWS was challenged in 2003 by the State of Maine and a number of businesses, such as Stolt Sea Farm, as being an 'arbitrary decision, capricious, an abuse of government

\footnotetext{
${ }^{154}$ Ibid.

${ }^{155}$ D.R. Boyd, Unnatural Law: Rethinking Canadian Environmental Law and Policy (UBC Press, 2003), at 193.

${ }^{156}$ Prepared by the National Marine Fisheries Services and Northeastern Region US Fish and the Wildlife Services, Final Recovery Plan for the Gulf of Maine Distinct Population Segment of Atlantic Salmon (November 2005), at 1-96, available at <http://www.nmfs.noaa.gov/ $\mathrm{pr} / \mathrm{pdfs} /$ recovery/salmon_atlantic.pdf $>$. See specifically at 4-6-4-7 for the suggested actions to minimize escapes in the Recovery Action Outline.

${ }^{157}$ See Northwest Regional Office, NOAA's National Marine Fisheries Service, Salmon Recovery Plans in Progress (NOAA, 30 August 2006), available at <http://www.nwr.noaa.gov/Salmon-RecoveryPlanning/ESA-Recovery-Plans/Draft-Plans.cfm>.

${ }^{158}$ Maine Marine Resource Laws, Title 12 - Conservation, Part 9 Marine Resources, Subpart II - Licencing, Section 6072 - Research and Aquaculture Leases, Section 7-B: 'Conditions, the commissioner may establish conditions that govern the use of the leased area and limitations on the aquaculture activities', available at <http:// www.maine.gov/dmr/lawsandregs/ laws.htm>

${ }^{159}$ Marine Pollution Discharge Elimination System, General Permit for Atlantic Salmon Aquaculture, MEG 130000, issued pursuant to 38 MRSA Section 413(10), Chapter 529, Code of Maine Regulations and Federal Water Pollution Control Act, 33 USC, Section 1251 et seq., Section I(2)(6), available at <http://www.maine.gov/dep/blwq/ docstand/wd/gp.htm>

160 Ibid.
} 
discretion, or not in accordance with the law' ${ }^{161}$ In Maine $v$. Norton, the State argued that the listing decision was improperly motivated, but the court determined that FWS's motivation was based on the best scientific evidence available and the State's case was dismissed.

Since 1997, the FWS had relied on the Maine Conservation Plan to protect wild salmon, but it became concerned over time about the plan's ability to respond to changing circumstances affecting the health of wild populations. One of these changes was increasing threats arising from aquaculture operations, such as escapes. The court's dismissal of the action and finding that FWS was 'reasonable in concluding that the aquaculture industry poses a potentially significant threat to the continued survival of the Gulf of Maine distinct population segment of Atlantic salmon' has, by necessity, driven regulatory reform in relation to escapes. ${ }^{162}$

The Maine aquaculture industry has been proactive in responding to the issue of escapes. In 1998, the Maine Aquaculture Association began developing a Code of Containment for the Responsible Containment of Farmed Atlantic Salmon in Maine Waters, which addresses equipment standards for nets, cages and mooring. ${ }^{163}$ Operating procedures, site selection, fish transfers, predator deterrence, vessel operation and storm preparation are covered by the code.

The aquaculture industry also collaborated with nongovernmental organizations (NGOs) in 2001, with an aim to create 'a predictable and stable regulatory climate for the aquaculture industry that minimizes interactions between sea-run and farmed salmon', ${ }^{164}$ and developed the Containment Management System (CMS). The CMS requires that aquaculture operations are designed to prevent consequential or accidental escapes and is based on a Hazard Analysis Critical Control Point (HACCP) system, which is a risk-analysis system that assigns critical control points in areas where the occurrence of escapes is a significant risk. ${ }^{165}$ The CMS is linked to the Code of Containment as it requires mooring and cage-net systems to meet or exceed the minimum standards in the code.

In 2003, the DEP made the CMS, and, therefore, the Code of Containment, a mandatory condition of its MePDES permits. ${ }^{166}$ One special condition required in the

\footnotetext{
${ }^{161}$ Maine v. Norton (2003) 257 F. Supp. 2d 357, 2003 U.S. Dist. Lexis 6911.

162 Ibid.

${ }^{163}$ Personal correspondence between T. Barry and M. Pietrak, Project Manager with the Maine Aquaculture Association (7 February 2005).

${ }^{164}$ Maine Aquaculture Association, Generic Containment Management System (Maine Aquaculture Association, 2001) provided through personal correspondence between T. Barry and M. Petrak, Project Manager with the Maine Aquaculture Association (7 February 2005), at 44.

${ }^{165}$ Ibid., at 46. See also M. Kesselring, n. 103 above and Marine Pollution Discharge Elimination System, n. 159 above, Section I(2)(6).

${ }^{166}$ See Marine Pollutant Discharge Elimination System, n. 159 above, at Part I: Protection of Atlantic Salmon, Section 6.
}

MePDES permit to protect wild salmon from escapes is the prohibition from using non-North American Atlantic salmon stock, using transgenic salmonids or from intentionally releasing salmon. ${ }^{167}$ The DMR makes obtaining a MePDES permit a mandatory aquaculture licensing condition in Section 6072, at 7-B of the Maine Marine Resource Laws. ${ }^{168}$ Since early 2005, the ACOE also requires 'functional marine containment management systems designed, constructed, and operated to prevent the accidental or consequential escape of fish to open water'. ${ }^{169}$

These advancements in permitting provisions to protect native Atlantic salmon are also linked to the decision in United States Public Interest Research Group et al. $v$. Stolt Sea Farms. ${ }^{170}$ In Stolt, two companies that engaged in operating salmon farms in Maine were taken to court by a public interest group for violating the requirements of the CWA. The court found the companies liable for polluting marine waters because of their escaping nonnative salmon species ${ }^{171}$ and concluded that "escapees can negatively affect endangered wild salmon by spreading pathogens and parasites and by competing for food, habitat, mates, and spawning sites.'. ${ }^{172}$ An injunction was granted forcing the companies to comply strictly with regulatory requirements, and an order was issued to stock only North American stock.

\section{Regulation of Escapes in Washington \\ State While the State of Washington was one of the} first to recognize and regulate aquaculture, information relating to escapes is sparse because escape reporting was not mandatory until 2001. ${ }^{173}$ Jurisdiction over regulating aquaculture in Washington State is split between the Washington Department of Fish and Wildlife (WDFW), which issues State permits for marine finfish aquaculture, ${ }^{174}$ and the Department of Ecology (DOE), which issues NPDES permits. ${ }^{175}$ The position of lead

\footnotetext{
${ }^{167}$ Ibid., Section 1.

168 See Maine Marine Resource Laws, n. 158 above, Section 6072, at 7-B.

${ }^{169}$ C. Fay et al., Status Review for Anadromous Atlantic Salmon (Salmo salar) in the United States, Report to the National Marine Fisheries and US Fish and Wildlife Service (July 2006), at 156, available at <http://www.nmfs.noaa.gov/pr/species/statusreviews.htm>. See also S. Horn-Olsen, n. 149 above.

170 United States Public Interest Research Group et al. v. Stolt Sea Farm (2003) US Dist. Lexis 8953. See also M. Kesselring, n. 103 above. 171 United States Public Interest Research Group v. Atlantic Salmon of Me., LLC, 215 F. Supp. 2d 239, 2002 US Dist. Lexis 2822; and see Clean Water Act, n. 150 above.

172 See United States Public Interest Research Group v. Atlantic Salmon, ibid., at 35.

${ }^{173}$ Personal correspondence between T. Barry and A. Thompson, Senior Aquaculture Officer - Pacific Region Fisheries and Oceans Canada (12 November 2003).

174 Washington Administrative Code, Title 220, Department of Fish and Wildlife, Chapter 76, Aquaculture, WAC Section 100, Marine finfish aquaculture - Approval Permit for Marine Finfish Aquaculture, available at <http://apps.leg.wa.gov/wac/>.

${ }^{175}$ Washington Administrative Code, Title 173, Department of Ecology, Chapter 220, National Pollution Discharge Elimination System Permit Program, available at <http://apps.leg.wa.gov/wac/>.
} 
agency for aquaculture has transferred between these departments as a result of legal proceedings. ${ }^{176}$

In 1997, a number of environmental groups appealed to the Pollution Control Hearings Board (PCHB), and challenged DOE's issuance of NPDES permits, to two aquaculture companies arguing that the permits authorized the discharge of pollutants, specifically the escape of farmed Atlantic salmon, in violation of water quality management standards. ${ }^{177}$ The PCHB found that the permits issued did not comply with the NPDES requirements because Atlantic salmon escapes were a 'pollutant' under the CWA. ${ }^{178}$ In 1998, the PCHB ruled that the farm needed to monitor the release of Atlantic salmon, ${ }^{179}$ and, in 1999, a motion was granted instructing the DOE to consider a $\mathrm{BC}$ report detailing the existence of self-sustaining populations of Atlantic salmon in determining whether their permits were adequate. ${ }^{180}$ The consortium continued to press for a finding that the NPDES permits issued in 1996 did not properly regulate the escapes; however, when the case was heard at the Court of Appeal in 2002, it was a moot point because the permits had expired. ${ }^{181}$

After the PCHB deemed Atlantic salmon escapes a 'pollutant' in 1997, the DOE became the lead jurisdiction for aquaculture because of its mandate to protect the marine environment, and to issue and enforce both the NPDES permits and Effluent Limitations Guidelines. ${ }^{182}$ In response to Environmental Consortium, the DOE amended the NPDES permits to require Fish Release Prevention and Monitoring Plans and Fish Release

${ }^{176}$ B. Mott, Re: Effluent Limitations Guidelines and New Source Performance Standards for the Concentrated Aquatic Animal Production Point Source Category, Letter to M. Jordan of the Office of Water, Engineering and Analysis Division, EPA, from Sea Web, Environmental Defense, Clean Water Network members and other interested parties (27 January 2003).

177 Marine Environmental Consortium, Washington Council, Protect our Waters and Natural Resources and Washington Trout v. State of Washington, Department of Ecology, Global Aqua-USA L.L.C. and Cypress Island Inc. (1997) Wa. Env. Lexis 188 ('Environmental Consortium'). 178 In ibid., the PCHB found that: (1) farmed salmon escaped from a 'point source'; (2) they constituted biological material; (3) are considered a waste because it is a commercial loss; and (4) are species that are non-native to the area.

${ }^{179}$ Marine Environmental Consortium, Washington Council, Protect our Waters and Natural Resources and Washington Trout v. State of Washington, Department of Ecology, Global Aqua-USA L.L.C. and Cypress Island Inc. (1998) Wa. Env. Lexis 111.

${ }^{180}$ Marine Environmental Consortium, Washington Council, Protect our Waters and Natural Resources and Washington Trout v. State of Washington, Department of Ecology, Global Aqua-USA L.L.C. and Cypress Island Inc. (1999) Wa Env Lexis 110.

${ }^{181}$ Marine Environmental Consortium Inc., Washington Trout and Washington Environmental Council Inc. v. State of Washington, Department of Ecology and State of Washington Pollution Control Hearings Board Inc. (2002) Wash. App. Lexis 1454.

182 Environmental Protection Agency, Extension of Comment Period for Effluent Limitations Guidelines and New Source Performance Standards for the Concentrated Aquatic Animal Production Point Source Category; Proposed Rule (EPA, 2 December 2002) available at <http://www.epa.gov/EPA-WATER/2002/December/Day-02/ w30466.htm>.
Response Plans. ${ }^{183}$ Both plans must be submitted to the DOE for approval and require best management practices to minimize escapes. ${ }^{184}$ The DOE has the authority to enter aquaculture facilities to investigate suspected violations and can enforce the NPDES permits by proceeding criminally or civilly, for compensation or to enjoin further violations. ${ }^{185}$

In 2001, lead jurisdiction for aquaculture shifted back to the WDFW through Bill 1499 because, under the State Environmental Policy Act, the WDFW is responsible for addressing potential impacts on salmon as a migratory species, and there was growing concern about raising non-native Atlantic species. ${ }^{186}$ Further permitting requirements of WDFW are an Escape Prevention Plan and an Escape Reporting and Recapture Plan; however, one plan can suffice for both the NPDES and the WDFW permit. ${ }^{187}$ Bill 1499 also suggested that Washington create a programme similar to the Atlantic Salmon Watch Program in BC; but this has been side-lined, and, instead, there is an informal understanding that the DOE, WDFW and $\mathrm{BC}$ will coordinate with each other concerning escapes. ${ }^{188}$

There is no code of containment in Washington State. The WDFW specifically reviewed other codes in North America and decided not to follow the prescriptive approach due to the perceived difficulty of keeping up to date with evolving best management practices. ${ }^{189}$ Therefore, WDFW adopted a prohibitory approach to regulating aquaculture, such that a farm is required to identify its fish, escapes are prohibited and farms are

\footnotetext{
${ }^{183}$ See Washington Administrative Code, n. 175 above.

${ }^{184}$ An example of permitting conditions can be found in Department of Ecology, National Pollution Discharge Elimination System Waste Discharge Permit for Cypress Island Inc., Site 2 - Deepwater Bay, WA-003157-7, 20 March 2002-20 March 2007, provided through personal correspondence between T. Barry and L. Levander, Ecology NWRO Water Quality (24 August 2006).

185 Washington Administrative Code, Title 2173, Department of Ecology, Chapter 173; Chapter 220, National Pollution Discharge Elimination System Permit Program, WAC Section 230, Enforcement, available at $<\mathrm{http}: / /$ apps.leg.wa.gov/wac/>.

${ }^{186}$ Washington State, Department of Ecology, State Environmental Policy Act, Chapter 43.21C RCW, available at <http://www. leg.wa.gov/ RCW/index.cfm?fuseaction=chapterdigest\&chapter $=43.21 \mathrm{C}>$. See also British Columbia Environmental Assessment Office, n. 119 above, at Vol. 4, Part C. See also Second Substitute House Bill 1499, Chapter 86, Laws of 2001, 57th Legislature (22 July 2001), provided through personal correspondence between T. Barry and L. Levander, Ecology North West Regional Office Water Quality (4 March 2005). ${ }^{187}$ Washington Administrative Code, Title 220, Department of Fish and Wildlife, Chapter 76, Aquaculture, WAC Section110, Escape Prevention Plan Required, at Section 2, and WAC Section 120, Escape Reporting and Recapture Plan Required, available at $<$ http://apps.leg.wa.gov/wac/>. Personal correspondence between T. Barry and A. Appleby, Fish Biologist with the Science Division of the Washington Department of Fish and Wildlife (7 March 2005).

${ }^{188}$ See personal correspondence between T. Barry and A. Appleby, ibid. See also Washington Administrative Code, Chapter 220, Department of Fish and Wildlife, Chapter 76, Aquaculture, WAC Section 149, Atlantic Salmon Watch Program Established, available at <http://apps.leg.wa.gov/wac/>.

${ }^{189}$ See correspondence between T. Barry and A. Appleby, ibid.
} 
penalized when their fish are found out of pen and unreported. ${ }^{190}$

\begin{abstract}
Alaska's Ban The stance taken by Alaska on salmon aquaculture practices in its jurisdiction, and subsequently escapes, exemplifies the problems caused by the transboundary issue of escapes. In May 1987, the Alaskan legislature passed a bill placing a moratorium on issuing permits for finfish farming in Alaskan waters in the Pacific. In 1990, this moratorium was upgraded to law under the Fish and Game Act, ${ }^{191}$ prohibiting marine finfish farming in order to prevent the threat of irreversible damage to the economically important wild salmon populations. In spite of this outright ban, the first documented recovery of an Atlantic salmon in Alaska occurred in the early 1990s, and by 2002, almost 600 Alaskan recoveries were documented. ${ }^{192}$
\end{abstract}

The Alaska Department of Fish and Game (ADFG) produced a White Paper on the issue of Atlantic salmon aquaculture in 1999, which was updated in 2002. This document describes how the ADFG considers escaped Atlantic salmon 'biological pollution' and 'an enormous potential threat to wild Pacific salmon' ${ }^{193}$ In the 2002 update to the White Paper, the ADFG made 11 proposals to $\mathrm{BC}$ and Washington State on how to minimize the effect of escapes, ${ }^{194}$ which includes revoking permits until 'zerorisk management' policies are adopted and allowing only land-based salmon farming. ${ }^{195}$ Neither Washington State

\footnotetext{
${ }^{190}$ See Washington Administrative Code, n. 174 above.

${ }^{191}$ Alaska Department of Fish and Game, Fish and Game Act, 16, A.K.C., 16.40 .210 (1990).

${ }^{192}$ See White Paper, n. 3 above.

193 Ibid., at 11.

194 Ibid.

${ }^{195}$ Ibid., at 11. The proposals are as follows: '[A] Until land-based operations are phased in, the following changes are proposed to minimize the risk for marine based farming operations: (1) Adopt a "zero risk management" policy in lieu of B.C.'s failed "Management Risk" policy; (2) Replace the B.C. Agricultural Ministry as the primary permitting and oversight agency for salmon farms with the B.C. Fisheries Ministry; (3) Stop the deliberate release of hundreds of thousands of small "non-performing" Atlantic and Pacific salmon; (4) Provide branding, monitoring and inventory methods to accurately identify, assess and control deliberate and accidental releases. Farmed fish must be branded with tags or otolith marks to identify the farm from which the escapes occurred, to allow tracking of escapees. Tagging and marking all farmed fish would also allow positive identification of the wild-born offspring of escaped farmed Atlantic salmon; (5) Allow only female or $100 \%$ triploid (sterile) Atlantic and Pacific salmon in marine net-pens to reduce the risk of feral populations or hybridization; (6) Allow no marine farms north of present locations to minimize risks to Alaskan farmed salmon; (7) Immediately cap salmon production in existing farms at current levels until phased out within a specified time frame; (8) Provide an absolute prohibition on Atlantic salmon egg and broodstock importation in lieu of the current voluntary program: (9) Negligent escapement of farmed fish should be subject to administrative sanctions (including immediate revocation of permits) and civil action by damaged parties. The farmed salmon industry must understand that continued escapement or deliberate release of thousands of farmed salmon annually will result in further restrictions, including fines, closing farms with poor records, forfeiture of permits, and the eventual closing down of the industry; (10) Any government subsidies should be disclosed and eventually phased out for all
}

nor BC accepted these proposed courses of action; however, there has been limited progress on three of the proposals. ${ }^{196}$ Alaska has taken no further actions based on these proposals and has not updated the White Paper since 2002, due to economic forces involved in international matters. ${ }^{197}$

\section{POSSIBLE FUTURE COURSES}

Getting a fix on future law and policy directions for preventing escape of farmed salmon is difficult for at least three reasons. First, possible technological solutions like the use of sterile fish and closed containment systems continue to be controversial in light of industry concerns ${ }^{198}$ and current costs. ${ }^{199}$ Second, jurisdictions have fundamentally differed in their regulatory approaches to preventing escapes, with Alaska banning salmon farming in the ocean altogether and Washington State prohibiting escapes while still allowing finfish farming. In contrast to what might be called 'prohibitory' approaches, other jurisdictions have attempted to control escapes through special regulations, ${ }^{200}$ licence conditions and codes of conduct. ${ }^{201}$

The third reason why the future direction is difficult to map is because a wide array of initiatives might be envisaged to strengthen approaches to addressing salmon escapes. They include, among others:

- concluding a global aquaculture agreement establishing containment standards; ${ }^{202}$

non-conforming operations. The industry must immediately comply with all existing regulations including the currently unenforced regulations that require containment nets with mesh small enough to contain all the fish. The industry must develop a written plan and timetable for improving control, marking all farmed fish and implementing effective marine containment for both fish and fish waste; and (11) Washington State must implement government oversite over farms and report releases'.

${ }^{196} \mathrm{BC}$ and Washington State have had limited progress in responding to proposals 3, 9 and 11. Personal correspondence between T. Barry and R. Piorkowski, Invasive Species Program Coordinator, Alaska Department of Fish and Game (21 July 2006).

${ }_{197}$ Personal correspondence between T. Barry and B. Piorkowski, Invasive Species Program Coordinator, Alaska Department of Fish and Game (11 October 2006).

198 Industry concerns regarding the use of sterile fish include their poorer performance in the sea, the frequency of deformities and adverse consumer reaction to sterile fish. See 'Report of a Meeting between the International Salmon Farmers' Association (ISFA) and Representatives of the NASCO Secretariat', Report of the TwentyThird Meeting, n. 5 above, Annex 21, (CNL(06)19), at 213.

199 See Report of the Ad Hoc Technical Expert Group on Mariculture, n. 39 above, at 26. The move to closed containment and land-based systems also has obvious financial implications to existing fish farms that have invested in open-net pen technology.

${ }^{200}$ As in BC, see Aquaculture Regulation, n. 124 above.

${ }^{201}$ For example, as in Newfoundland and Labrador and Maine, see Code of Containment, n. 112 above.

202 The attraction of such an option would be to establish a 'level playing field' whereby salmon aquaculture operations around the globe, including in Chile, Scandinavia, Europe, Australia and North America, would be subject to common standards. However, States at present seem to be content with 'soft guidelines' on aquaculture. See FAO Technical Guidelines, n. 45 above. 
- bolstering of transboundary environmental impact assessment procedures; $;^{203}$

- resorting to the citizen complaint procedure under the North American Agreement for Environmental Cooperation (NAAEC), ${ }^{204}$ available where a member country is not effectively enforcing its environmental laws relating to aquaculture; ${ }^{205}$

- requesting an aquaculture reference to the International Joint Commission in order to assess transboundary impacts of aquaculture and recommend ways to enhance transboundary cooperation; ${ }^{206}$

- addressing aquaculture escapes under new CanadaUS regional seas agreements for the Gulf of Maine and North Pacific in implementation of the ecosystem approach; ${ }^{207}$

\footnotetext{
${ }^{203}$ For example, finfish aquaculture operations carrying risks of marine escapes might be listed as an activity subject to transboundary environmental impact assessment under the Convention on Environmental Impact Assessment in a Transboundary Context (Espoo, 25 February 1991) adopted under the umbrella of the United Nations Economic Commission for Europe. Pursuant to the North American Security and Prosperity Partnership, launched by government leaders from Canada, Mexico and the United States in 2005, one of the action items includes development of a transboundary environmental impact assessment cooperation agreement for proposed projects which, if it is forged, could be tailored to consider transboundary aquaculture impacts. See Report to Leaders: Security and Prosperity Partnership of North America (June 2005), available at <http://www. spp.gov/report_to_leaders/ index.asp?dName=report_to_leaders>.

${ }^{204}$ North American Agreement on Environmental Cooperation (Mexico City, Ottawa, Washington, 14 September 1993).

${ }^{205}$ Articles 14 and 15 of the NAAEC allow any NGO or person to make a submission to the Secretariat that a party is failing to enforce effectively its environmental law whereupon the Secretariat can recommend the development of a factual record; ibid. For an overview and critique of the process, see J. Kirton and S. Richardson, The Commission for Environmental Cooperation: Lessons for Canada United States Regulatory Cooperation, Government of Canada Policy Research Initiative, Working Paper Series 024 (April 2006).

${ }^{206}$ Boundary Waters Treaty (Washington DC, 11 June 1909), Article IX allows questions or matters of differences arising between Canada and the USA along the common frontier to be referred to the International Joint Commission for examination and recommendations. For a further discussion of the reference process, see D.L. VanderZwaag et al., 'Decision-Making Improvement and Alternatives', in A. Rieser et al. (eds), Environmental Decision-Making in a Transboundary Region (Springer-Verlag, 1986), 155, at 169-172; and J.L. Sax and R.B. Keiter, 'The Realities of Regional Resource Management: Glacier National Park and its Neighbors Revisited', 33:2 Ecology L.Q. (2006), 233, at 294.

${ }^{207}$ Recent discussions at the Seventh Session of the UN Informal Consultative Process on Oceans and Law of the Sea on the ecosystem approach have emphasized the need to take an integrated management approach to transboundary ecosystems and might be a basis for catalysing development of new comprehensive regional seas agreements for both the east and west coasts of Canada (and possibly the Beaufort Sea as well), where aquaculture development/management would be included among other sectoral issues needing to be addressed on a cooperative basis. See Report of the Seventh Session of the Informal Consultative Process on Oceans and Law of the Sea (A/ 61/156, 17 July 2006), available at <http://www.un.org/Depts/los/ consultative_process/consultative_process.htm\#A/61/156>.
}

- discussing escape issues and management responses within State-provincial transboundary arrangements for the east and west coasts; ${ }^{208}$

- using informal governmental discussion opportunities to consider and compare existing divergent escape-prevention approaches; ${ }^{209}$ and

- seeking third-party resolution of transboundary disputes over aquaculture, for example through establishment of a conciliation commission to address the tensions between Alaska and $\mathrm{BC}$ over net pen aquaculture operations. ${ }^{210}$

While these various avenues remain as possibilities, this article focuses on two future regional courses for dealing with transboundary escapes and appropriate regulatory responses. The courses are enhancing the NASCO framework for preventing escapes; and placing transboundary aquaculture issues on the 'radar screen' of North Pacific regional arrangements.

\section{ENHANCING THE NASCO FRAMEWORK}

NASCO has already set in motion initiatives to enhance the organization's ability to influence aquaculture impacts on wild salmon including farmed salmon escapes. Following on from recommendations from a working group on the 'Next Steps of NASCO', which met in 2004 and 2005, ${ }^{211}$ and the incorporation of some of the recommendations in a Strategic Approach for NASCO's Next Steps in 2005, ${ }^{212}$ the Council of NASCO established a task force on 'Next Steps for NASCO'. The task force further reflected on ways to enhance implementation, commitment, accountability and transparency, and participatory dimensions. ${ }^{213}$ At the twenty-third annual

\footnotetext{
${ }^{208}$ See nn. 64-68 and 71-74 above, and accompanying texts.

${ }^{209}$ For example, the Canada/USA Steering Committee co-chaired by the Director-General of the Maritimes Region Fisheries and Oceans Canada and by the Regional Administrator of NOAA's National Marine Fisheries Service in the USA has recently established a Species at Risk Working Group. Personal communication between D. VanderZwaag and M. Westhead, Project Leader, Bay of Fundy/ Gulf of Maine, Fisheries and Oceans Canada (4 July 2006). The group could become a central conduit for raising the profile of escaped salmon and the need to address preventative standards.

${ }^{210}$ For overviews on possible routes to resolving marine environmental protection and law of the sea disputes, see J.I. Charney, 'The Implications of Expanding International Dispute Settlement Systems: The 1982 Convention on the Law of the Sea', 90:1 AJIL (1996), 69; A.N. Craik, 'Recalcitrant Reality and Chosen Ideals: The Public Function of Dispute Settlement in International Environmental Law', 10 Geo. Int'l Envtl L. Rev. (1998), 551. The binding dispute procedures under UNCLOS would, of course, not apply in light of the non-party status of the USA.

${ }^{211}$ See NASCO, 'Report of the "Next Steps for NASCO" Working Group', Report of the Twenty-Second Annual Meeting of the Council, Vichy, France, 6-10 June 2005 (CNL(05)50, 10 June 2005), Annex 15 (CNL(05)14).

212 'Strategic Approach for NASCO's Next Steps', ibid., Annex 16 (CNL(05)49).

${ }^{213}$ See Report of the Twenty-Third Meeting, n. 5 above.
} 
meeting of the NASCO Council, a number of measures recommended by the task force were adopted to strengthen implementation of NASCO agreements including the Williamsburg Resolution on Minimizing Impacts from Aquaculture. NASCO parties agreed that each party should develop an implementation plan for meeting the objectives of NASCO's agreements over at least 5 years, that annual reports on actions taken under the implementation plan would be submitted, including aquaculture-related actions, and that more in-depth action reports would be submitted to special sessions of the council. ${ }^{214}$ To provide a critical review mechanism for looking at the implementation plans, the council agreed to establish an $A d H o c$ review group, consisting of party and NGO representatives, to critique the adequacy of the implementation plans. ${ }^{215}$

The council at its twenty-third meeting only decided on the role of the Ad Hoc Review Group for the coming year, with a focus on evaluating national implementation plans. Hopefully, the review process will be extended beyond 2007 to include future critiques of annual reports and special session reports so that countries can be pushed to provide full details of efforts to manage aquaculture operations including the challenges of escapes.

The adequacy of the existing NASCO Guidelines should be subject to further review. At the very least, the guidelines might set out more specific guidance on technical standards for net pens, ${ }^{216}$ training requirements for escape prevention $^{217}$ and installation of security systems. ${ }^{218}$ The guidelines might also harmonize escape reporting

\footnotetext{
${ }^{214}$ NASCO's Council adopted the Guidelines for the Preparation of NASCO 'Implementation Plans' and for Reporting on Progress, which were prepared by the 'Next Steps' Task Force. The guidelines are aimed at strengthening reporting for implementation of the three main agreements: fishery management; protection and restoration of habitat; and aquaculture and associated activities. The guidelines are attached as Annex 3 to the Report of the Task Force on Implementation of the Next Steps for NASCO, Asturias, Spain, 31 January-3 February 2006 (NSTF(06)13, 3 February 2006). For the council decision, see Report of the Twenty-Third Meeting, n. 5 above, at 5 .

${ }^{215}$ The Terms of Reference for the 2006/2007 Ad Hoc Review Group are attached as Annex 16 (CNL(06)39) to the Report of the TwentyThird NASCO Meeting, n. 5, above. The composition of the group is recommended to consist of one person from Denmark in respect of either the Faroe Islands or Greenland, two persons from the remaining parties to NASCO, one person from the Standing Scientific Committee and two persons from accredited NGOs.

${ }^{216}$ Existing equipment and structural standards are exceedingly general; for example Section 4.1 calls for nets, cages and mooring systems to be designed, constructed and deployed to prevent escapes, while Section 4.6 urges salmon farming systems to be upgraded, as improved, site-appropriate and cost-effective systems of proven efficacy become available. See NASCO Guidelines, n. 15 above.

${ }^{217}$ Section 5.1 is very generic regarding training: 'farm management procedures shall ensure supervision by appropriately trained, qualified or experienced personnel'; ibid.

${ }^{218}$ Section 5.8 only makes a general recommendation on security systems: 'where practicable, security systems should be installed so as to deter acts of vandalism and malicious damage'; ibid.
}

requirements by defining what constitutes a significant escape for reporting purposes. ${ }^{219}$ National authorities might also be directed to require contingency plans for escapes ${ }^{220}$ and third-party audits to verify escape preparedness. ${ }^{221}$

Whether the NASCO Convention needs a major 'make over' also should be a priority consideration. While the idea of transforming NASCO from being a recommendary body to a regulatory entity has not been embraced by NASCO parties, ${ }^{222}$ the increasing role of potential aquaculture impacts on wild salmon stocks should elevate the question of whether the mandate of NASCO should be expanded to address aquaculture more specifically. For example, NASCO might be tasked with developing a harmonized approach to addressing salmon escapes and could be granted authority to develop mandatory escape-prevention standards. Disputeresolution provisions for resolving possible conflicts over aquaculture development threats and impacts might also be established under an amended convention.

\section{PLACING TRANSBOUNDARY AQUACULTURE ISSUES ON THE AGENDAS OF NORTH PACIFIC REGIONAL ARRANGEMENTS}

While two regional salmon conservation bodies exist, the PSC and the NPAFC, neither commission has focused upon aquaculture issues, at least partly explained by convention frameworks, which emphasize the management of salmon fisheries and supportive scientific research. The PST makes no mention of aquaculture and its principal aims are to prevent over-fishing, to provide for optimum production of salmon stocks and to encourage salmon enhancement programmes. ${ }^{223}$ Research under the umbrella of the PSC has been directed towards fisheries-related issues. ${ }^{224}$ The Convention for the Conservation of Anadromous Stocks in the North Pacific Ocean also makes no reference to aquaculture, and the convention is aimed at prohibiting directed fishing for anadromous fish in the convention

\footnotetext{
${ }^{219}$ Section 6.2 calls upon operators to advise appropriate authorities immediately in case of significant escapes but each jurisdiction is given discretion to define 'significant escape' under its national action plan in implementation of the guidelines; ibid.

${ }^{220}$ Section 6.3, which calls for site-specific contingency plans to be developed, does not clearly place the obligation on regulatory authorities; ibid.

${ }^{221}$ On the need for third-party audits, see L.P. Hansen and M.L. Windsor, n. 51 above, at 1161.

${ }^{222}$ For a discussion of varying views on the need for transforming NASCO into a regulatory body, see NASCO Council, Report of the Stakeholder Consultation Meetings on the 'Next Steps for NASCO' (CNL(05)13, January, 2005).

${ }^{223}$ See Pacific Salmon Treaty, n. 16 above, at Article III.

${ }^{224}$ Information on the work conducted by the Pacific Salmon Commission, Role of the Commission (Pacific Salmon Commission), available at <http://www.psc.org/about_role.htm>.
} 
area ${ }^{225}$ and minimizing the incidental taking of anadromous fish. ${ }^{226}$

The North Pacific Anadromous Fisheries Science Plan 2006-2010 does not mention aquaculture impacts as a research area, even though an ecosystem-based approach is advocated. ${ }^{227}$ The plan proposes to focus research in two areas: namely, better scientific information on the status and trends in marine production of anadromous stocks and the effects of climate change on such stocks and related species.

Both Pacific conventions dealing with salmon contain language that could be interpreted to allow at least limited consideration of aquaculture issues, including escapes. The Convention for the Conservation of Anadromous Stocks in the North Pacific Ocean sets out the overall objective of the commission as the promotion of the conservation of anadromous stocks in the convention area. ${ }^{228}$ Parties are required to cooperate in conducting scientific research in the North Pacific Ocean and its adjacent seas beyond 200 nautical miles from territorial sea baselines for the purposes of the "conservation of anadromous stocks, including, as appropriate, scientific research on other ecologically related species'. ${ }^{229}$ The PST in its preambular language emphasizes the interests of both parties to ensure the conservation and rational management of Pacific salmon stocks. ${ }^{230}$

A potential avenue for putting acquaculture environmental impacts on the agenda of NPAFC is through future cooperation with NASCO, which has already embraced dealing with aquaculture threats to wild salmon. A Discussion Document on Enhancing Cooperation between NPAFC and NASCO, attached to NPAFC's Annual Report $2005,{ }^{231}$ raises the possibility of not only jointly convening an international symposium, ${ }^{232}$ perhaps in 2008/

\footnotetext{
${ }^{225}$ See NPAFC Convention, n. 17 above, at Article III(1)(a). Article 1 defines the convention area as waters of the North Pacific Ocean and its adjacent seas, north of 33 degrees north latitude beyond 200 nautical miles from the baselines from which the territorial sea is measured. ${ }^{226}$ Ibid., Article III(1)(b).

${ }^{227}$ North Pacific Anadromous Fish Commission, NPAFC Science Plan (NPAFC, undated), available at <http://www.npafc.org/new/ science_plan.html>.

${ }^{228}$ See NPAFC Convention, n. 17 above, Articles VIII(2) and VII(1). ${ }^{229}$ Ibid., Article II(8) further provides that the Commission may make recommendations to or advise the parties on any matter relating to the treaty.

${ }^{230}$ See Pacific Salmon Treaty, n. 16, Appendix 13, available at <http://www.npaf.org/new/pbulications/Annual\%20Report/2005/ Appendices/ Appendix13>.

${ }^{231}$ See NPAFC, Annual Report 2005 (NPAFC, 2005), available at <http://www.npafc.org/new/publications/Annual\%20Report/2005/ Appendices/Appendix13.htm>. The document notes a previous cosponsored meeting on Causes of Marine Mortality of Salmon in the North Pacific and North Atlantic Oceans and in the Baltic Sea, which was held in Vancouver, BC in March 2002.

${ }^{232}$ The document suggests, as a likely symposium topic, understanding of the factors influencing mortality of salmon at sea. Ibid., Appendix 13 , Section 2.3
}

๑ 2007 The Authors. Journal compilation ๔ 2007 Blackwell Publishing Ltd.
$2009,{ }^{233}$ but also suggests other possible areas for improved cooperation relating to scientific research and management. The document notes NASCO's active involvement in applying the ecosystem approach and the precautionary approach to issues such as fisheries management, minimizing impacts of aquaculture and introductions and transfers, and habitat protection and restoration. ${ }^{234}$

While it remains to be seen whether aquaculture impacts will eventually be addressed by the Pacific commissions through a broad interpretation of their mandates, perhaps the time is near for revisiting the existing treaty mandates in light of the evolving ecosystem approach. ${ }^{235}$ The approach highlights the need to take into account factors originating outside the boundaries of defined management areas that may influence marine ecosystems, ${ }^{236}$ and supports the use of integrated decision-making processes and management of multiple sectors. ${ }^{237}$ One way of achieving an ecosystem approach could be by modernizing the mandates of regional fisheries organizations. ${ }^{238}$ Clear mandates that address the transboundary effect of escapes could help to guide cross-boarder discussion and coordination on the issue of escapes.

\section{CONCLUSION}

Preventing the escape of farmed salmon could be quite simple. As in Alaska, a total ban on farming salmon in ocean net pens could be imposed. Raising finfish in landbased facilities with protective barriers to prevent escapes into watercourses and the sea is a trend being pushed under the CBD.

However, getting a firmer grip on escape prevention in Canada and the USA is anything but easy. Most jurisdictions have allowed extensive farming of salmon at sea and, thus, powerful political and economic currents have been established against the tide of prohibition in favour of regulation or voluntary controls.

\footnotetext{
${ }^{233}$ Ibid., Section 2.2.

${ }^{234}$ Ibid., Section 3.2. Key differences in the NASCO and NPAFC contexts should be noted, including the reality that more coastal States around the North Atlantic share concerns about escaped salmon.

${ }^{235}$ For a discussion of the uncertainties still surrounding the approach, see D.R. Rothwell and D.L. VanderZwaag, 'The Sea Change Towards Principled Ocean Governance', in D.R. Rothwell and D.L. VanderZwaag (eds), Towards Principled Ocean Governance: Australian and Canadian Approaches and Challenges (Routledge, 2006), 3, at 6.

${ }^{236}$ See Agreed Consensual Elements to be Suggested to the General Assembly for Consideration under its Agenda Item Entitled "Oceans and the Law of the Sea"', Report of the Seventh Session of the Informal Consultative Process, n. 207 above, Part A, at para. 6(d).

237 Ibid., para. 6(i).

238 Ibid., para. 7(e).
} 
At the international and regional levels, only minimal and general guidance has been provided to address escape risks. For example, how the principle of State responsibility not to cause transboundary environmental damage and the obligation to protect and preserve the marine environment relate to salmon farm escapes remains open to debate. NASCO's Guidelines, having no counterpart for the Pacific coast, remain voluntary and are lacking in clear containment standards.

Future directions for addressing transboundary escape issues remain unclear with a spectrum of further responses possible. They include, among others, firming up containment standards under the NASCO Guidelines; amending existing agreements aimed at conserving wild salmon stocks to address aquaculture threats specifically; and forging new integrative and ecosystem-based ocean management arrangements for Pacific and North-West Atlantic waters where aquaculture would be addressed in broader contexts.

With many hurdles in the way of amending treaties and creating new regional ocean governance arrangements, including State sovereignty concerns and the complexity of federal-provincial/State relations, perhaps at least the process of cross-border learning and aquaculture policy debate could be furthered by convening a symposium or workshops on transboundary challenges and approaches to managing aquaculture. NASCO and the NPAFC would be the most obvious institutions for leading a symposium initiative. Academic institutions in Canada and the USA might also collaborate in organizing bi-national workshops relating to aquaculture management, including prevention of escapes. Resolving aquaculture law and policy tensions and divergencies will likely involve a 'long swim' but more cooperative 'strokes' are clearly needed.

Tricia K. Barry, LL.B., graduated from Dalhousie University, Halifax, Canada, in 2005, with a certificate of specialization from the Marine \& Environmental Law Institute. She is a member of the Nova Scotia Barristers Society and the Law Society of British Columbia. She is currently clerking for the Nova Scotia Court of Appeal.

David L. VanderZwaag is Professor of Law and Canada Research Chair in Ocean Law and Governance at the Marine \& Environmental Law Institute, Dalhousie Law School. He holds cross-appointments with the School for Resource and Environmental Studies and the International Development Studies Programme at Dalhousie and co-chairs the International Union for Conservation of Nature and Natural Resource's Specialist Group on Oceans, Coasts and Coral Reefs.

The authors wish to acknowledge the research support from the Social Sciences and Humanities Research Council of Canada and the research assistance of Thea Lowry, Research Assistant, Marine \& Environmental Law Institute, Dalhousie Law School. 